Article

\title{
Constraining Mantle Heterogeneity beneath the South China Sea: A New Perspective on Magma Water Content
}

\author{
Wei Wang ${ }^{1,2} \mathbb{D}$, Fengyou Chu ${ }^{1,2, *}$, Xichang Wu ${ }^{2}$, Zhenggang $\mathrm{Li}^{2} \mathbb{D}$, Ling Chen ${ }^{2}, \mathrm{Xiaohu} \mathrm{Li}^{2}$, \\ Yuanzi Yan ${ }^{3}$ and Jie Zhang ${ }^{2}$ \\ 1 School of Earth Sciences, Zhejiang University, Hangzhou 310027, China \\ 2 Key Laboratory of Submarine Geosciences, Second Institute of Oceanography, Ministry of Natural \\ Resources, Hangzhou 310012, China \\ 3 Department of Geology, Northwest University, Xi'an 710069, China \\ * Correspondence: chu@sio.org.cn; Tel.: +86-0571-8196-3202
}

Received: 27 May 2019; Accepted: 1 July 2019; Published: 4 July 2019

\begin{abstract}
The nature of upper mantle is important to understand the evolution of the South China Sea (SCS); thus, we need better constrains on its mantle heterogeneity. Magma water concentration is a good indicator, but few data have been reported. However, the rarity of glass and melt inclusions and the special genesis for phenocrysts in SCS basalts present challenges to analyzing magmatic water content. Therefore, it is possible to estimate the water variations through the characteristics of partial melting and magma crystallization. We evaluated variations in Fe depletion, degree of melt fractions, and mantle source composition along the fossil spreading ridge (FSR) using SCS basalt data from published papers. We found that lava from the FSR $116.2^{\circ} \mathrm{E}, \mathrm{FSR} 117.7^{\circ} \mathrm{E}$, and non-FSR regions can be considered normal lava with normal water content; in contrast, lava from the FSR $117^{\circ}$ E-carbonatite and 114.9-115.0 $0^{\circ} \mathrm{E}$ basalts have higher water content and show evidence of strong Fe depletion during the fractional crystallization after elimination of the effects of plagioclase oversaturation. The enriched water in the $117^{\circ}$ E-carbonatite basalts is contained in carbonated silicate melts, and that in the 114.9-115.0 $\mathrm{E}$ basalts results from mantle contamination with the lower continental crust. The lava from the $117^{\circ}$ E-normal basalt has much lower water content because of the lesser influence of the Hainan plume. Therefore, there must be a mantle source compositional transition area between the southwestern and eastern sub-basins of the SCS, which have different mantle evolution histories. The mantle in the west is more affected by contamination with continental materials, while that in the east is more affected by the Hainan mantle plume.
\end{abstract}

Keywords: water content; mantle source; Hainan plume; lower continental crust; South China Sea

\section{Introduction}

The formation of the South China Sea (SCS) has always been a hot topic in research, with multiple genetic models being explored [1-8], and the key research area for the petrologist is the nature of the upper mantle. However, such studies have been limited by the lack of fresh volcanic samples. In recent years, an abundance of igneous samples from volcanic seamounts near the $15.5^{\circ} \mathrm{N}$ fossil spreading ridge (FSR) has provided a newfound opportunity to investigate the nature of the upper mantle under the SCS [9-13]. The geochemical study of volcanic samples from the area show that the nature of the upper mantle is quite complicated, with Dupal anomaly characteristics, ocean island basalt (OIB)-like properties [9-14], mantle contamination from the Hainan mantle plume [15-18], recycled continental materials [13], and the presence of carbonated silicate melts [9]. Therefore, we need a better method for constraining mantle heterogeneity to help us understand the evolutionary history of the SCS. 
Water is one of the most important volatile components in magma and mantle sources; it significantly influences mantle partial melting and magma crystallization [19-21], and can be treated as an incompatible element [22-24]. Thus, the water content of magma is a good indicator of magma heterogeneity in the mantle source. However, data on magmatic water content in SCS basalt are limited.

The lack of water content data for SCS magma provides the motivation for this study. Yet, the rarity of glass and melt inclusions in the basalt presents a challenge to analyzing the magma water content. Recent research has outlined the potential of using nominally anhydrous minerals (NAMs), especially clinopyroxene, to constrain magmatic water content based on the experimentally determined partition coefficients; these minerals have since been used in a number of studies to determine magma water content [25-27]. However, recent studies on the geochemical characteristics of clinopyroxenes in SCS basalts show that phenocryst clinopyroxenes are megacrysts crystallized from parent magma with the same source as the host lava [28,29]. In other words, the clinopyroxenes are products of the mantle plume that are not affected by the interaction between the mid-ocean ridge and the mantle plume. The Mg\# of the phenocryst clinopyroxenes in SCS basalts varies from 0.84 to 0.92 [28]; then, we calculated the Mg\# values of the parental magma equilibrium with these clinopyroxenes by using the $\mathrm{Fe}=\mathrm{Mg}$ exchange coefficient between clinopyroxene and silicate melts (Kd: 0.3, [30,31]). The result shows that the Mg\# varies from 0.61 to 0.78 , which is significantly higher than the Mg\# of the host lava (0.34 to 0.59 , [28]), suggesting a disequilibrium between clinopyroxenes and the host lava [28,29]. The high Mg\# of parental magma exhibited really primitive characteristics, and the lack of a zonal structure of clinopyroxenes also reflects the deep crystallization from relatively undifferentiated magma. Hence, we suggest that the water content data from clinopyroxene cannot be used to reflect the magma water content beneath the SCS.

The most effective way to obtain information regarding the distribution characteristics of magma water content beneath the FSR of SCS is to estimate water variation using the characteristics of partial melting and magma crystallization. During the process of fractional crystallization, the water content in the magma significantly controls the appearance of plagioclase crystallization [32-34]. The plagioclase, a mineral group poor in $\mathrm{FeO}^{*}$, is the second phase in the cotectic line during anhydrous fractional crystallization under a pressure of one atmosphere [33,35-37]. The onset crystallization of plagioclase leads to a sudden increase of $\mathrm{FeO}^{*}$ and decrease of $\mathrm{Al}_{2} \mathrm{O}_{3}$ in magma, and retards $\mathrm{Mg}$ depletion. The addition of water to the magma then causes a significant suppression of plagioclase crystallization and results in Fe depletion in the magma [32-34]. Zimmer et al. [38] developed a quantitative index for this Fe depletion (Tholeiitic Index, THI $=\mathrm{Fe}_{4.0} / \mathrm{Fe}_{8.0}$ ), and found that water correlates negatively with THI, and this relationship is maintained within the basaltic magma (including arc volcanoes, back-arc basins, ocean islands and mid-ocean ridges). Therefore, Fe depletion and the corresponding magma CA characteristics (magma fractionation trend from tholeiitic (TH) to calc-alkaline (CA)) can be used to reflect the magma water content. During the process of mantle melting, the water concentration and mantle potential temperature $\left(T_{P}\right)$ are the most important effects on the melting regimes. An increase in $T_{P}$ at constant water in the source causes an increase in the initial melting depth, the mean extent of melting, and the crustal thickness. The addition of water to the mantle source at constant $T_{P}$ also causes an increase in the initial melting depth and crustal thickness because water is diluted by further melting, and has little effect on the maximum extent of melting. However, the addition of water lowers the melting temperature of the solidus and increases the area of mantle flow that crosses the solidus. Thereby, it increases the denominator in the definition of the mean extent of melting (F), and causes a decrease in the mean extent of melting [39]. Based on these characteristics, it helps to identify high water mantle sources.

In this study, we use SCS basalt data from published papers to evaluate variations in CA characteristics (Fe depletion), the degree of mantle melting, and mantle source composition along the FSR. We gain a certain understanding of the variations in magma water content along the FSR, which provides us with better constraints for the origin of high water content and mantle heterogeneity in the SCS. 


\section{Geological Background}

The SCS is located at the intersection of the Eurasian, Indo-Australian, and Pacific plates, and is the largest continental marginal basin in the west Pacific (Figure 1). The SCS has undergone a series of tectonic evolution processes, from subduction during the late Mesozoic to continental extension and seafloor spreading during the Cenozoic [2,40-43]. The spreading finally stopped at $15.5 \mathrm{Ma}$ [40-42]. Three fossil spreading ridges $\left(18^{\circ} \mathrm{N}, 17^{\circ} \mathrm{N}\right.$, and $\left.15.5^{\circ} \mathrm{N}\right)$ and several sub-basins (the northwestern, southwestern, and eastern) remain. The eastern sub-basin has a lower average water depth than the other sub-basins because of the large number of seamounts formed along the youngest FSR $\left(15.5^{\circ} \mathrm{N}\right.$, 23-15.5 Ma; [44]). These seamounts are products of extensive intraplate volcanism that occurred after the ridge spreading ceased. In addition, a low-velocity anomaly has been observed beneath the Hainan Island area, and the hot spot-type volcanism at that location may be caused by the deep-mantle Hainan plume $[45,46]$. The range of influence of the Hainan plume was constrained by the presence of alkali basalts and includes the SCS, the Leiqiong Peninsula, Hainan Island, Vietnam, and Thailand [10,47,48].

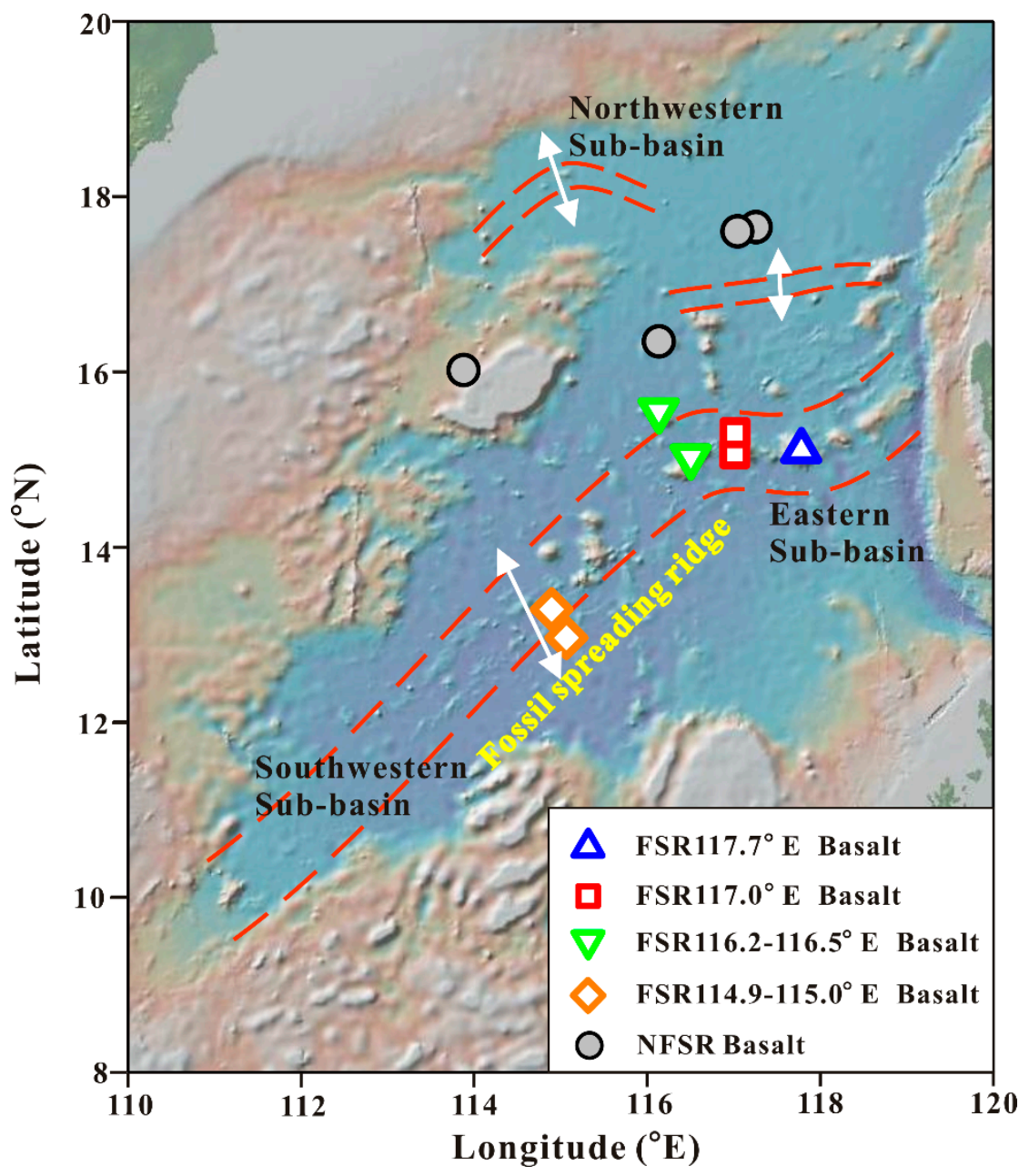

Figure 1. The geological setting of the South China Sea (SCS) and data location. Red dotted lines represent the fossil spreading ridge (FSR), white arrows show the ridge spreading directions, colored labels identify the basalt samples collected from the FSR, and the gray circle surrounds the basalt samples collected far from the FSR.

\section{Data Sources and Quality Control}

The major, trace, and isotope composition data used in this study are exclusively from published articles; the data sources are shown in Table 1. All the basalt data were merged, where the total Fe 
$\left(\mathrm{FeO}_{\mathrm{T}}\right)=0.9 \times \mathrm{Fe}_{2} \mathrm{O}_{3 \mathrm{~T}}$. Due to the lack of interlaboratory bias correction factors, we did not calibrate the major and trace element data from interlaboratory variations. However, all the methods for obtaining major and trace element data are consistent: using X-ray fluorescence (XRE) and inductively coupled plasma mass spectrometry (ICP-MS), respectively, with precisions of approximately $<5 \%$ and $<10 \%$, respectively. Therefore, the obtained data are of good quality. For isotope data, especially $\mathrm{Pb}$ isotope data, there are indeed significant differences between those of earlier and recent studies for the same samples. All of our Pb isotope data were obtained within the years from 2007 to 2018 (Table 1), except for the $\mathrm{Pb}$ isotope data from Tu et al. [10] (which were obtained in 1997). Li et al. [49] suggested that old $\mathrm{Pb}$ isotope data should be superseded by new ones obtained from the same samples, and samples that have not been reanalyzed should be excluded. However, in our study, we retained the $\mathrm{Pb}$ isotope data from Tu et al. [10], because these are the only $\mathrm{Pb}$ isotope data for a certain area $\left(117.7^{\circ} \mathrm{E}\right)$, and this data has only been used as background information. The $\mathrm{Sr}$ and $\mathrm{Nd}$ isotope data were renormalized to ${ }^{87} \mathrm{Sr} /{ }^{86} \mathrm{Sr}=0.71025$ for NBS $987 \mathrm{Sr}$ standard and ${ }^{143} \mathrm{Nd} /{ }^{144} \mathrm{Nd}=0.511860$ for the La Jolla Nd standard. Further, in order to ensure data quality, highly evolved ( $\mathrm{MgO}<3.0 \mathrm{wt} . \%$ and $\mathrm{SiO}_{2}<43$ wt. \%) and highly primitive $\left(\mathrm{MgO}>12\right.$ wt. \% and $\mathrm{SiO}_{2}>55 \mathrm{wt}$. \%) compositions were excluded.

Table 1. The data sources for the samples used in this study.

\begin{tabular}{|c|c|c|c|}
\hline \multirow{2}{*}{ Location } & \multicolumn{3}{|c|}{ Data Source } \\
\hline & Major Element & Trace Element & Pb Isotope \\
\hline FSR & $\begin{array}{l}\text { Zhang et al. [9], Tu et al. [10], } \\
\text { Yan et al. [11], Li et al. [12], } \\
\text { Zhang et al. [13]. }\end{array}$ & $\begin{array}{l}\text { Zhang et al. [9], Tu et al. [10], } \\
\text { Yan et al. [11], Zhang et al. [13]. }\end{array}$ & $\begin{array}{l}\text { Zhang et al. [9], Tu et al. [10], } \\
\text { Yan et al. [11], Zhang et al. [13]. }\end{array}$ \\
\hline NFSR & $\begin{array}{l}\text { Yan et al. [11], Yan et al. [50], } \\
\text { Yang and Fang [51]. }\end{array}$ & $\begin{array}{c}\text { Yan et al. [11], Yan et al. [50], } \\
\text { Yang and Fang [51]. }\end{array}$ & $\begin{array}{c}\text { Yan et al. [11], Yan et al. [50], } \\
\text { Yang and Fang [51]. }\end{array}$ \\
\hline Hainan OIBs & Wang et al. [17], Wang et al. [52]. & Wang et al. [17], Wang et al. [52]. & $\begin{array}{l}\text { Zou and Fan, [15], Li et al. [16], } \\
\text { Wang et al. [52], Han et al. [53]. }\end{array}$ \\
\hline
\end{tabular}

NFSR: non-FSR basalt, OIB: ocean island basalt.

We divided the collected SCS basalt data into two main groups. The first group of basalt samples landed on the FSR at $15.5^{\circ} \mathrm{N}$ (see the colored labels in Figure 1). We subgrouped FSR basalts according to longitude in order to explore the heterogeneity of the sub-ridge mantle in greater detail: FSR $117.7^{\circ}$ E, FSR 117.0 $0^{\circ}$ E-carbonatite (FSR 117.0 E-C), FSR 117.0 E-normal (FSR 117.0 $0^{\circ}$ E-N), FSR $116.2^{\circ} \mathrm{E}$ (including $116.2-116.5^{\circ} \mathrm{E}$ basalts), FSR $114.9-115.0^{\circ} \mathrm{E}$. In the figure, the corresponding labels are the blue triangle, hollow red square, solid red square, green inverted triangle, and orange diamond, respectively (Figure 1). The second group of basalt samples landed far from the FSR (non-FSR basalt, NFSR; the gray circle in Figure 1), and was used for comparison with the FSR data. We also used Hainan OIB data to examine the effects of the Hainan plume.

\section{Results}

Numerous studies have been conducted on the geochemical characteristics of major, trace, and isotope compositions of SCS basalts [9-13,50]. The general geochemical features show that SCS basalts have large variations in major element composition and plot in the transitional field between the alkaline and sub-alkaline magmatic series. Sub-alkali and alkali basalts have different melting characteristics in depth, degree of melting, and even the different ages [54,55]. Some supports are shown in the primary melt composition calculated by using the PRIMELT3 MEGA.XLSM software (version 3, produced by Herzberg and Asimow [56]). The details of the volcanic rock total alkali silica (TAS) classification and primary melt calculation are shown in Supplementary Materials Section S1, S3, and Figure S1. Trace element compositions mainly manifest as enriched mid-ocean ridge basalt (E-MORB) and OIB-like rare earth element (REE) patterns enriched in light REE (LREE), the details of chondrite-normalized REE patterns, and primitive mantle-normalized incompatible trace element patterns are shown in Supplementary Materials Section S1, Figures S2 and S3. Isotope compositions are similar to those of an Indian-type mantle with Dupal anomaly characteristics. The aim of this 
study was not to repeat a previous result, but rather to try and reveal the following characteristics from our compiled data: (1) the CA characteristics and Fe depletion within the SCS basalt, and (2) the along-fossil spreading ridge geochemical variation.

\subsection{CA Characteristics and Fe Depletion in SCS Basalt}

SCS basalt data are plotted against mid-ocean ridge basalts (MORBs) and volcanic arc basalts in Figure 2, a FeO $* / \mathrm{MgO}^{-\mathrm{SiO}_{2}}$ diagram, to observe the CA characteristics in SCS basalt. The vast majority of SCS basalts (excluding some basalt from the FSR $114.9-115.0^{\circ} \mathrm{E}$ and $117^{\circ} \mathrm{E}-\mathrm{N}$ ) are tholeiitic in character, and the variation range of the CA characteristics in SCS basalts is smaller than that of the MORBs and arc basalt data. In order to quantify the extent of Fe depletion using the Miyashiro diagram [57], the delineating fields of high-Fe, medium-Fe, and low-Fe from Arculus [58], and the different values of the $\mathrm{CA} / \mathrm{TH}$ index lines proposed by Hora et al. [54] have been added to the $\mathrm{FeO}^{*} / \mathrm{MgO}-\mathrm{SiO}_{2}$ diagram. The results show that half of the $114.9-115.0^{\circ} \mathrm{E}$ and $117.0^{\circ} \mathrm{E}-\mathrm{N}$ basalt samples fall within the medium-Fe area, and the other half fall within the high-Fe field (Figure 2). We quantified Fe depletion by calculating the $\mathrm{CA} / \mathrm{TH}$ index for each basalt sample using the equation from Hora et al. [54]: $\mathrm{CA} / \mathrm{TH}$ index $=\left(\mathrm{SiO}_{2}\right.$ wt. \% -42.8$) /\left(6.4 \times \mathrm{FeO}^{*} / \mathrm{MgO}\right)$. The $117.0^{\circ} \mathrm{E}-\mathrm{N}$ and 114.9-115.0 $\mathrm{E}$ basalt data show the highest $\mathrm{CA} / \mathrm{TH}$, with average values of $0.83 \pm 0.23$ and $0.81 \pm 0.15$, respectively. They are followed by the FSR $117.0^{\circ} \mathrm{E}-\mathrm{C}$ basalt data with the variation range of $0.12-0.84$, while the FSR $117.7^{\circ} \mathrm{E}$, FSR $116.2^{\circ} \mathrm{E}$, and NFSR basalt data show a similar relatively small CA/TH variation range of approximately $0.1-0.5$.

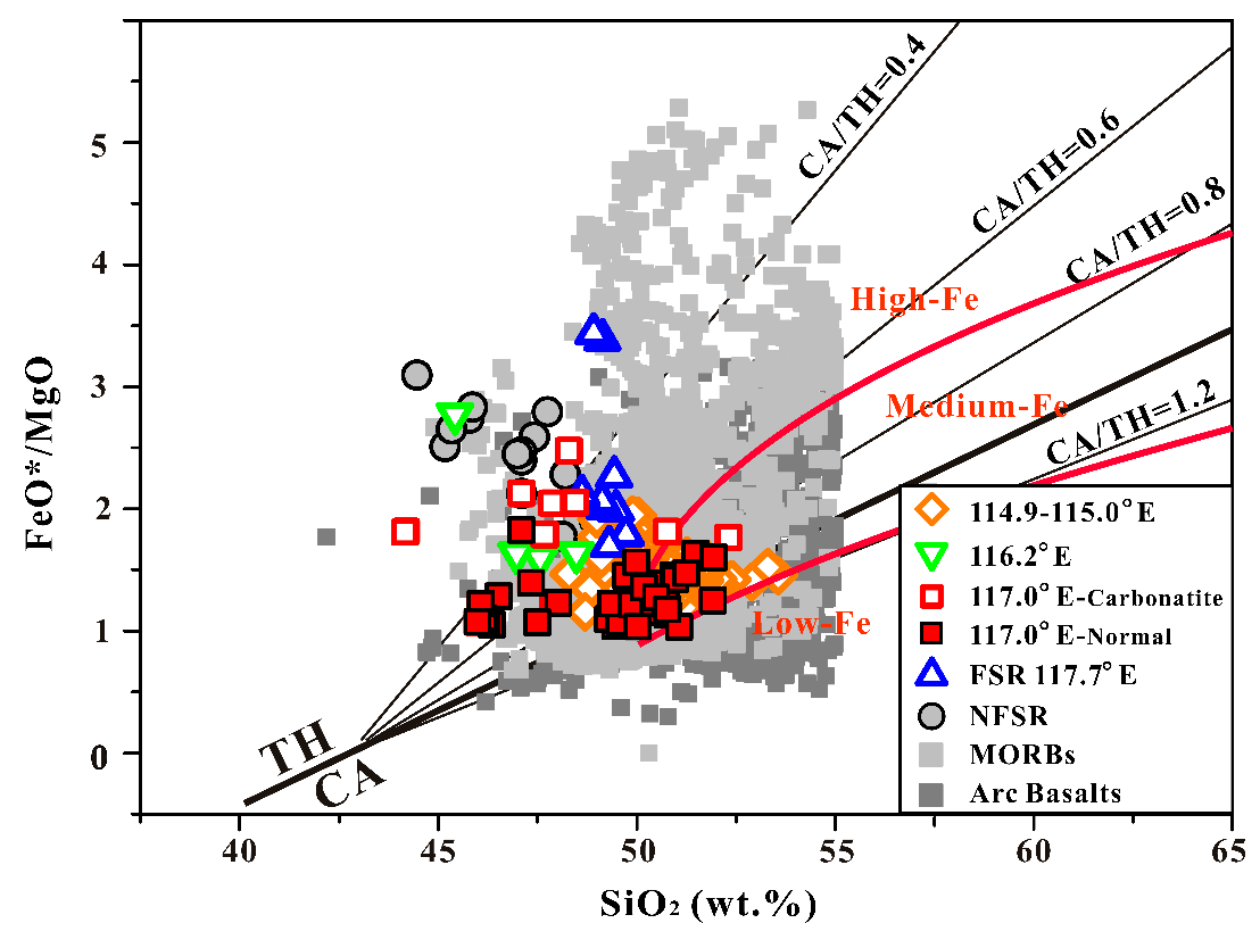

Figure 2. $\mathrm{FeO}^{*} / \mathrm{MgO}$ vs. $\mathrm{SiO}_{2}$ discrimination diagram with the dividing line from Miyashiro [57]. The light gray solid squares show the global mid-ocean ridge basalts (MORBs) compiled reported in Gale et al. [59]. The gray solid squares show volcanic arc basalts from the PetDB database [60]. TH represents the tholeiitic, and CA is calc-alkaline. The thick black solid line is the TH-CA dividing line, which is determined by the equation $\mathrm{SiO}_{2}($ wt. $\%)=6.4 \times\left(\mathrm{FeO}^{*} / \mathrm{MgO}\right)+42.8$ [57]. The red solid lines delineate the fields of high-Fe, medium-Fe, and low-Fe, according to Arculus [58]. The thin black solid lines indicate different CA/TH indexes from Hora et al. [54].

It is worth noting that the different $\mathrm{CA} / \mathrm{TH}$ values of each basalt group indicate that there are big differences in the degree of $\mathrm{FeO}^{*}$ depletion. In Figure 3A, it is clearly observable that all the SCS 
basalt data can be divided into two different groups based on $\mathrm{FeO}^{*}$ concentration $\left(\mathrm{FeO}^{*}=10.5\right.$ wt. $\%$ ). The FSR $117.7^{\circ} \mathrm{E}$ and NFSR basalt are significantly more enriched in FeO* than the other basalts, and the maximum $\mathrm{FeO}^{*}$ content is available when $\mathrm{MgO}$ is approximately $5 \mathrm{wt} \%$, and suggests that the magnetite begins to crystallize. Further, it can be seen in the basalts with lower FeO* concentration that $\mathrm{FeO}^{*}$ seems gradually decreases with decrease in $\mathrm{MgO}$ (Figure 3A). Most basalt samples with lower $\mathrm{FeO}^{*}$ concentrations also correspond to the higher concentration in $\mathrm{Al}_{2} \mathrm{O}_{3}$ (Figure $3 \mathrm{~B}$ ).
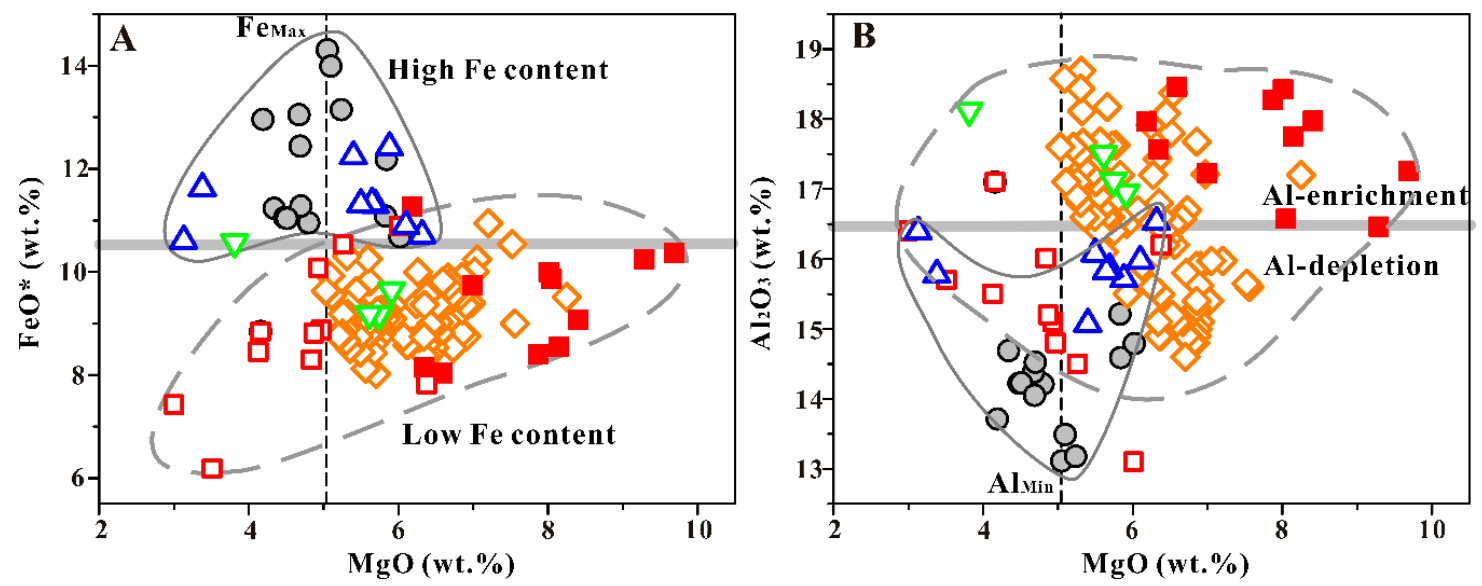

Figure 3. The $\mathrm{MgO}$ vs. FeO* plot (A) and $\mathrm{MgO}$ vs. $\mathrm{Al}_{2} \mathrm{O}_{3}$ plot (B) for SCS basalts. The symbols here represent the same things as those in Figure 2.

Although the $117.0^{\circ} \mathrm{E}-\mathrm{C}$ basalt has a smaller $\mathrm{CA} / \mathrm{TH}$ value than the $117.0^{\circ} \mathrm{E}-\mathrm{N}$ basalt, both show similar low $\mathrm{FeO}^{*}$ concentration. The possible reason for this is that the degree of magma evolution affects the quantification of Fe depletion: the $117.0^{\circ} \mathrm{E}-\mathrm{C}$ basalt is highly evolved with much lower $\mathrm{MgO}$ and $\mathrm{SiO}_{2}$ (Figures 2 and 3). Moreover, one must be more careful while determining the degree of depletion in Fe (or enrichment in $\mathrm{Al}$ ) in basaltic magma by comparing concentrations or CA characteristics. The depletion in Fe (or enrichment in $\mathrm{Al}$ ) can be overestimated due to clustering of some basalt data with high $\mathrm{Al}$ and low Fe content, which are the result of plagioclase accumulation/assimilation or high magma water content.

\subsection{Geochemical Variation along the FSR}

The depletion or enrichment of Fe in basaltic magma may reflect the magma water content, because the water content of the parental magma can significantly affect the liquid lines of descent (LLD) curve, especially the appearance of plagioclase [30-32]. Therefore, we selected $\mathrm{K}_{2} \mathrm{O}$ and Ce, which have the similar incompatibilities with water during the mantle melting and magma fractional crystallization, to reflect the possible magma water content variation trend along the FSR (Figure 4B,C). The effect of the degree of partial melting on incompatible elements is discussed in a later section in this paper. The $\mathrm{K}_{2} \mathrm{O}$ and $\mathrm{Ce}$ concentration have similar variation trends along the FSR with the maximum values appearing at the $117^{\circ} \mathrm{E}-\mathrm{C}$ basalt. However, the $117^{\circ} \mathrm{E}-\mathrm{N}$ basalt exhibits the lowest $\mathrm{K}_{2} \mathrm{O}$ and $\mathrm{Ce}$ values similar to the $114.9-115.0^{\circ} \mathrm{E}$ basalt. The FSR $117.7^{\circ} \mathrm{E}, \mathrm{FSR} 116.2^{\circ}$ E, and NFSR basalts show similar characteristics in terms of $\mathrm{K}_{2} \mathrm{O}$ and $\mathrm{Ce}$.

We also used $\mathrm{Pb}-\mathrm{Sr}-\mathrm{Nd}$ isotopic analysis to determine the along-axis sub-ridge mantle source compositional variation. The $\mathrm{Pb}-\mathrm{Sr}-\mathrm{Nd}$ isotopic variations with longitude are shown in Figure 4D-F. All of the isotopic variations in the SCS basalt fall within the isotopic variations in the Indian MORB (Figure 4D-F: orange area, Indian MORB data from Gale et al. [59]), suggesting that the mantle source obviously is subject to the Indian MORB mantle signature [61]. Most of the isotopic variations in the SCS basalt also fall within those of Hainan OIBs (Figure 4D-F: light green area), except for the 114.9-115.0 $0^{\circ} \mathrm{E}$ and $117^{\circ} \mathrm{E}-\mathrm{N}$ basalts, suggesting the high influence of the Hainan mantle plume. The lava from the FSR $114.9-115.0^{\circ}$ E has a completely different isotopic composition from those of 
other lavas in the SCS, and are characterized by lower ${ }^{87} \mathrm{Sr} /{ }^{86} \mathrm{Sr}$ and ${ }^{206} \mathrm{~Pb} /{ }^{204} \mathrm{~Pb}$ and much higher ${ }^{143} \mathrm{Nd} /{ }^{144} \mathrm{Nd}$. Such differences suggest possible localized mantle source contamination or possible mantle source isotopic transition (Figure 4D-F: vertical dotted area). The $117^{\circ} \mathrm{E}-\mathrm{N}$ basalt shows slightly smaller ${ }^{87} \mathrm{Sr} /{ }^{86} \mathrm{Sr},{ }^{206} \mathrm{~Pb} /{ }^{204} \mathrm{~Pb}$ and higher ${ }^{143} \mathrm{Nd} /{ }^{144} \mathrm{Nd}$ values than the surrounding basalt, which may be explained by the weak influence of the Hainan plume.
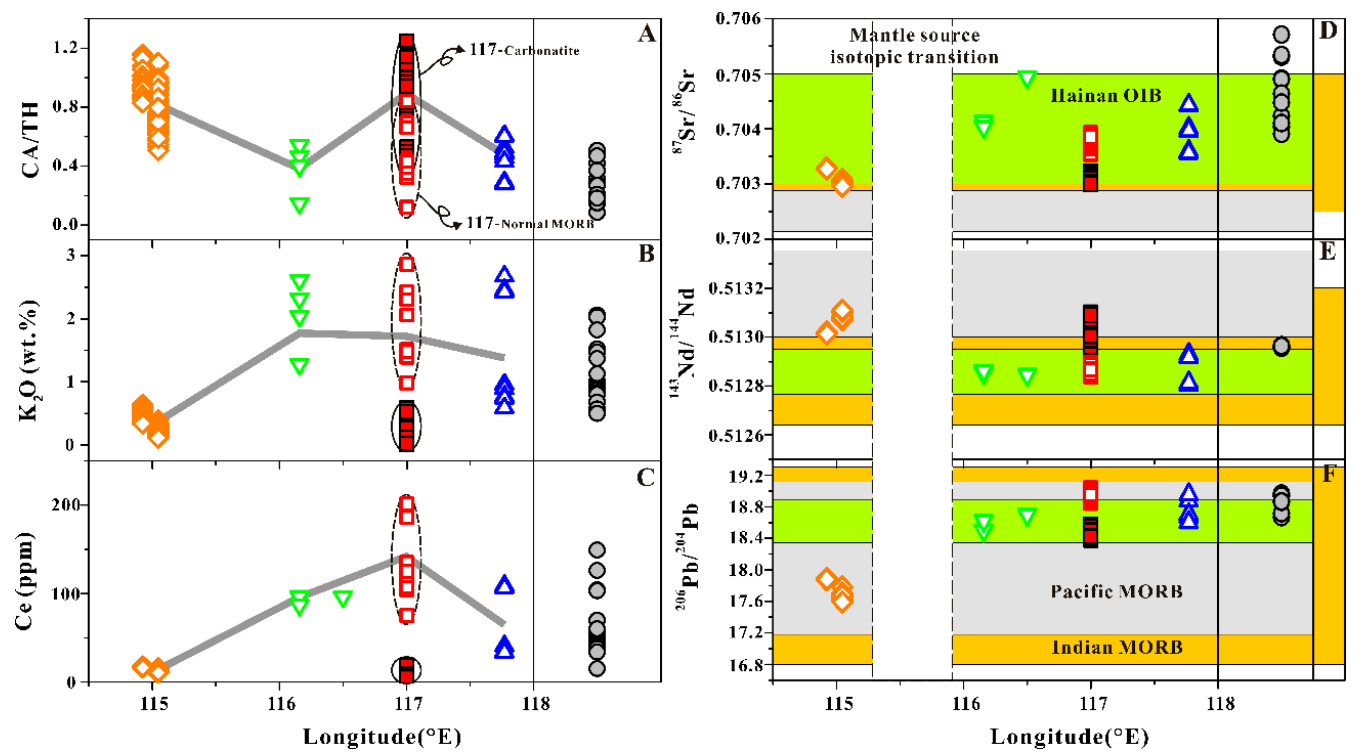

Figure 4. Geochemical variation along the FSR in CA characteristics (CA/TH) (A), $\mathrm{K}_{2} \mathrm{O}(\mathbf{B}), \mathrm{Ce}(\mathbf{C})$, ${ }^{87} \mathrm{Sr} /{ }^{86} \mathrm{Sr}(\mathbf{D}),{ }^{143} \mathrm{Nd} /{ }^{144} \mathrm{Nd}(\mathbf{E})$, and ${ }^{206} \mathrm{~Pb} /{ }^{204} \mathrm{~Pb}(\mathbf{F})$. The CA/TH value for each SCS basalt is shown in the Supplementary Table S1. The isotopic composition of the Pacific MORB and Indian MORB are from Gale et al. [59], Hainan OIB data from Zou and Fan [15], Li et al. [16], Wang et al. [52], and Han et al. [53]. The vertical dotted areas in (D-F) represent possible mantle source isotopic transitions. Symbols in the figure represent the same objects as those in Figure 2.

\section{Discussions}

\subsection{Mantle Melting}

The $\mathrm{Na}_{8.0}$ value and the calculated melt fractions (F) for each sample along the FSR are plotted in Figure 5. Figure $3 \mathrm{~A}$ shows that the crystallization of magnetite begins at approximately $\mathrm{MgO}=5 \mathrm{wt}$. $\%$. Therefore, we filtered out samples with $\mathrm{MgO}<5 \mathrm{wt}$. \% before the calculation, because only the LLDs that reflect stable ol + plag +/- cpx crystallization can be used to calculate the $\mathrm{Na}_{8.0}$ and $\mathrm{F}$ values effectively. The $\mathrm{Na}_{8.0}$ was calculated by correcting the $\mathrm{Na}_{2} \mathrm{O}$ to $8.0 \mathrm{wt}$ \% of $\mathrm{MgO}$ using the expression from Klein and Langmuir [62]. Figure 5 shows that, except the FSR 114.9-115.0 $0^{\circ}$ basalt, the other basalt $\mathrm{Na}_{8.0}$ value gradually decreases from $116.2^{\circ} \mathrm{E}$ to the east, and the NFSR basalt data show the lowest $\mathrm{Na}_{8.0}$ value, which infers the highest extent of mantle melting. We noticed that the FSR $117^{\circ}$ $\mathrm{E}-\mathrm{N}$ basalt have a similar $\mathrm{Na}_{8.0}$ value to that of the $117^{\circ} \mathrm{E}-\mathrm{C}$ basalt or even a little bit higher, which indicates a close degree of melting. However, the degree of fractionation between the LREE and HREE in these two groups of basalt shows a great difference $\left(\mathrm{La} / \mathrm{Yb}\right.$ of $117^{\circ} \mathrm{E}-\mathrm{C}$ and $117^{\circ} \mathrm{E}-\mathrm{N}$ basalt are $22.0 \pm 9.45$ and $1.16 \pm 0.56$, respectively). Thus, we also used $\mathrm{TiO}_{2}$ as a single element proxy for the melt fraction, even though in case of low melt fractions, the F indicated by $\mathrm{Ti}$ is not sensitive to $\mathrm{Na}_{8.0}$. Nonetheless, as a high field-strength element, Ti has low mobility in aqueous fluids [63].

In order to calculate the degree of melting, we need to correct the $\mathrm{TiO}_{2}$ content to the composition of primary magma. We have two different methods and the results are shown in Supplementary Table S2; the first one uses the PRIMELT3 MEGA.XLSM software [56] for primary magma calculation. However, the calculation result of F may be underestimated; see the details in Supplementary Section 
S3. The second method is using the LLD to do the step-by-step reverse calculation. Firstly, we corrected the $\mathrm{TiO}_{2}$ to 8.0 wt. \% and 8.5 wt. \% of $\mathrm{MgO}$ using the expression from Kelley et al. [64]. Then, $\mathrm{TiO}_{2(\mathrm{Fo} 90)}$ was calculated using $8.5 \mathrm{wt}$. \% of $\mathrm{MgO}$ equivalent compositions by adding equilibrium olivine to each basalt composition in 1\% increments until equilibrium with Fo90 was reached [66]. The last step for the $\mathrm{F}$ value was calculated by using $\mathrm{TiO}_{2(\mathrm{Fo90})}$ and the batch melting equation from Kelley et al. [64]. The melt fractions calculated using $\mathrm{TiO}_{2}$ composition are basically the same as those exhibited by $\mathrm{Na}_{8.0}$ for all the basalt samples except for the FSR $117^{\circ} \mathrm{E}-\mathrm{N}$ basalts. The FSR $117^{\circ} \mathrm{E}-\mathrm{N}$ basalt exhibits a relatively high degree of mantle melting similar to the $114.9-115.0^{\circ} \mathrm{E}$ basalt, while the other groups of basalt show relatively low melt fractions. Therefore, the variations in the incompatible elements ( $\mathrm{Ce}$ and $\mathrm{K}_{2} \mathrm{O}$ ) may be caused by the difference in the degree of melting or be related to the mantle source. We discuss this in Section 5.3.

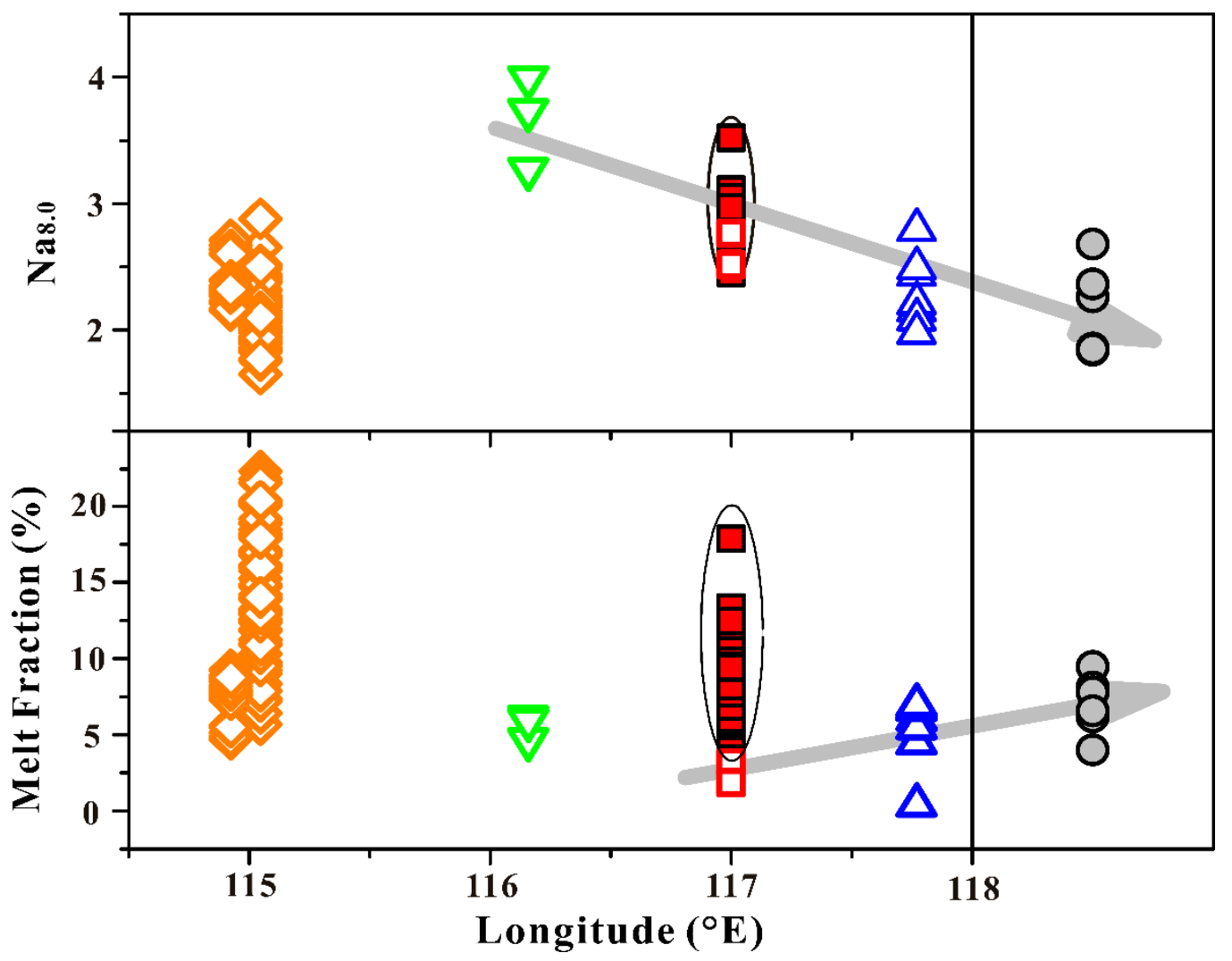

Figure 5. Along FSR variation of $\mathrm{Na}_{8.0}$ and melt fraction. $\mathrm{Na}_{8.0}$ was calculated by correcting $\mathrm{Na}_{2} \mathrm{O}$ to 8.0 wt. \% of $\mathrm{MgO}$ using the expression $\mathrm{Na}_{8.0}=\mathrm{Na}_{2} \mathrm{O}-0.373 \times(8.0-\mathrm{MgO})$ from Klein and Langmuir [62]. The melt fraction was calculated by using $\mathrm{TiO}_{2(\mathrm{Fo} 90)}$ and the batch melting equation $F=\frac{\left(C_{T i}^{0} / C_{T i}^{1}\right)-D_{T i}}{\left(1-D_{T i}\right)}$ from Kelley et al. [64], where $C_{T i}^{0}$ is the concentration of $\mathrm{TiO}_{2}$ in the mantle source; here, we used the $\mathrm{TiO}_{2}$ concentration in the depleted mantle source (DM) $\mathrm{TiO}_{2}=0.119 \%$ (716.3 ppm). $C_{T i}^{1}$ is the concentration of $\mathrm{TiO}_{2}$ in the melt in equilibrium with $\mathrm{Fo} 90\left(\mathrm{TiO}_{2(\mathrm{Fo90})}\right)$. $\mathrm{D}_{\mathrm{Ti}}$ is the distribution coefficient for Ti during mantle melting; here, we used $\mathrm{D}_{\mathrm{Ti}}=0.058$ [65]. $\mathrm{TiO}_{2 \text { (Fo90) }}$ was calculated using 8.5 wt. \% of $\mathrm{MgO}$ equivalent compositions by adding equilibrium olivine to each basalt composition in $1 \%$ increments until equilibrium with $\mathrm{Fo} 90$ was reached [66]. The calculated $\mathrm{Na}_{8.0}$ and $\mathrm{F}$ value for each SCS basalt are shown in the Supplementary Table S1. In order to ensure that the LLDs reflect stable ol + plag +/-cpx crystallization, samples with $\mathrm{MgO}<5$ wt. \% were not used to calculated $\mathrm{Fe}_{8.0}, \mathrm{Na}_{8.0}$, and F. The symbols in this figure represent the same things as those in Figure 2.

After the filtering process, there are only two data left in the $117^{\circ} \mathrm{E}-\mathrm{C}$ basalt group, and only three data left in the group of $116.2^{\circ}$ E. Due to the small number of the samples, the representation is weak. Therefore, a trace elements melting model has also been used to reflect the melting characteristics for 
each group of SCS basalt data (Figure 6). We use a La/Yb versus Sm/Yb plot to distinguish the melting of garnet or spinel peridotite, because La and Sm are incompatible elements during mantle melting, while $\mathrm{Yb}$ is relatively compatible. Thus, $\mathrm{La} / \mathrm{Yb}$ and $\mathrm{Sm} / \mathrm{Yb}$ are strongly fractionated under the lower degree of melting. The $\mathrm{Sm} / \mathrm{Yb}$ ratio also reflects the proportion of residual garnet during lherzolite mantle melting, because garnet tends to strongly fractionate heavy REE (HREE) rather than middle REE (MREE) $[67,68]$. The SCS basalt data are plotted together with the batch melting curves calculated for garnet peridotite and spinel peridotite from Xu et al. [69] (Figure 6). Figure 6 demonstrates that nearly all SCS basalts resulted from various degrees of mantle melting in the garnet peridotite, and only the FSR $116.2^{\circ} \mathrm{E}$ basalt data fall far away from the garnet peridotite melting curve, which seems scattered between the garnet and spinel peridotite melting curves. The possible explanation for this is that the lowest initial melting depth caused the smallest proportion of garnet to have been involved in the mantle melting there, and the degree of melting indicated by melting model was lower than $5 \%$. In a single mantle source, additional water reduces the liquidus temperature [39] and increases the initial melting depth $[70,71]$. Thus, the lowest initial melting depth exhibited by the FSR $116.2^{\circ} \mathrm{E}$ basalt indicates that it is unlikely to contain a higher magma water content in its lava.

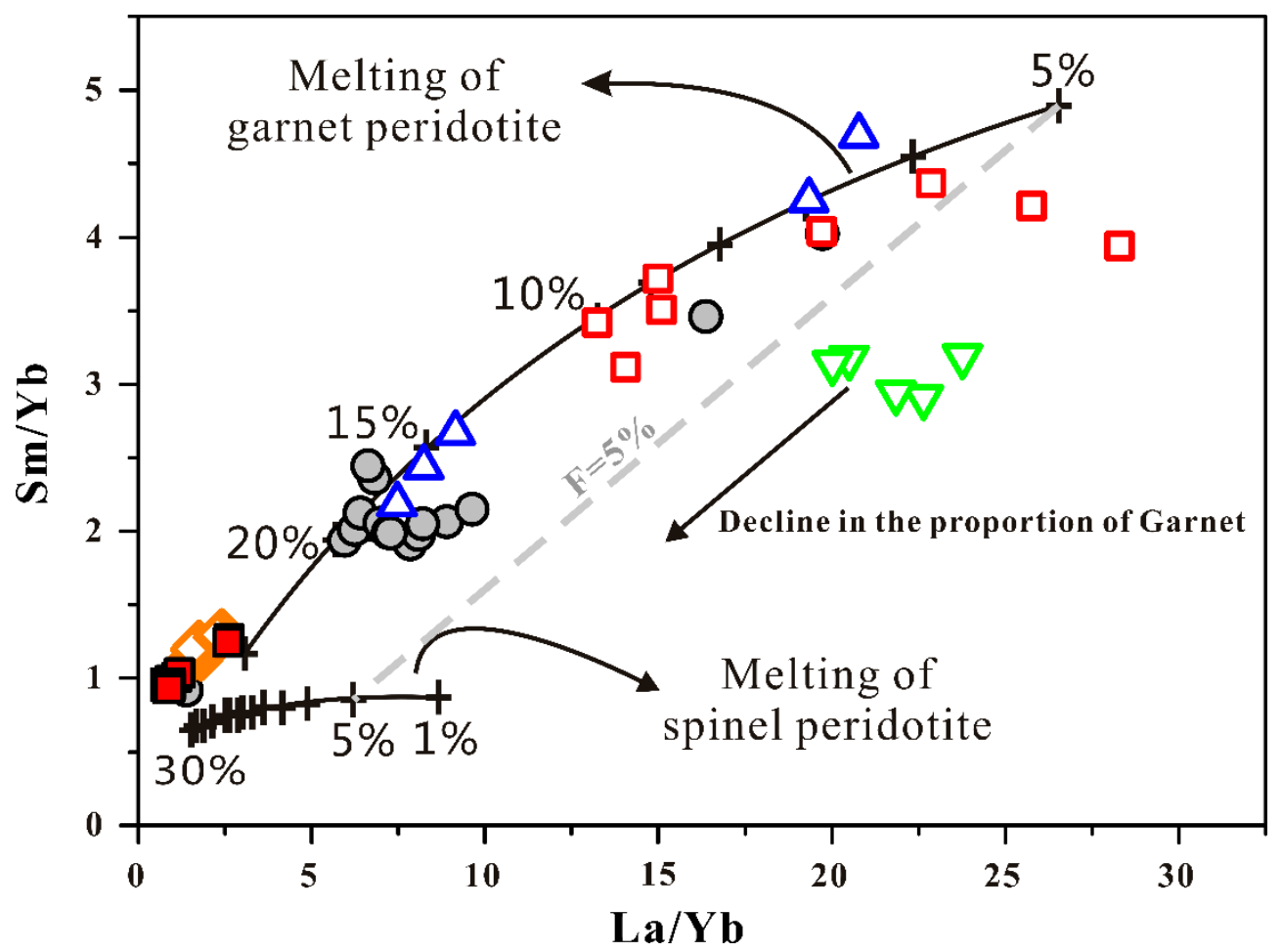

Figure 6. $\mathrm{La} / \mathrm{Yb}$ vs. $\mathrm{Sm} / \mathrm{Yb}$ for SCS basalts. The black solid lines are batch melting curves calculated for garnet peridotite and spinel peridotite mantle sources from $\mathrm{Xu}$ et al. [69]. For detailed parameters for establishing batch melting curves, such as partition coefficients, starting materials, and melting reactions in the garnet and spinel fields, see Xu et al. [69]. The symbols used in this figure represent the same things as those in Figure 2.

The degree of melting reflected by melting curves is much higher than the above calculation results; obviously, these values are overestimated, but the variations between different groups basalt along the FSR are consistent with the calculated $F$ values and even clearer when combined with the variation of the average melting depth revealed from the $\mathrm{FeO}^{*}$ content of primary magma (Supplementary Materials Section S3). Hence, we conclude that FSR $117^{\circ} \mathrm{E}-\mathrm{C}$ basalts have the lowest degree of melting, which is then followed by the FSR $117.7^{\circ} \mathrm{E}$ and NFSR. The basalt from $114.9-115.0^{\circ} \mathrm{E}$ and $117^{\circ}$ E-N exhibit the highest degree of melting and the lowest melting depth. In conclusion, the melting characteristics of FSR $117^{\circ} \mathrm{E}-\mathrm{C}$ are more like the hydrous melting. 


\subsection{Plagioclase Assimilation/Accumulation}

The addition of water to magma suppresses the onset of plagioclase crystallization and finally results in Fe depletion in the magma [32-34,38]. However, the Fe depletion in the basalt may have been overestimated, and therefore cannot be taken as a direct indicator of the water content of the magma. For example, the FSR $117^{\circ} \mathrm{E}-\mathrm{N}$ basalt exhibits the highest $\mathrm{CA} / \mathrm{TH}$ value (Figure $4 \mathrm{~A}$ ), and the FSR $116.2^{\circ}$ E basalt shows low Fe concentration characteristics (Figure 3A). However, they do not show the corresponding mantle melting characteristics such as low melt fraction and high initial melting depth. The reason for this is that plagioclase assimilation/accumulation in the bulk rock can produce lower $\mathrm{FeO}^{*}$ concentrations and higher $\mathrm{Al}_{2} \mathrm{O}_{3}[32,72,73]$. Therefore, we filter out crystal accumulation using $\delta \mathrm{Eu}<1$, and in order to minimize the effect of crystal accumulation, samples without trace element data were also not retained.

The FSR $116.2^{\circ} \mathrm{E}$ basalt shows an oversaturation of plagioclase crystals $(\delta \mathrm{Eu}=1.03 \pm 0.017)$, suggesting that the Fe depletion there was not caused by additional water in the magma. The filtered data for the FSR $117^{\circ} \mathrm{E}-\mathrm{N}$ basalt does not show strong Fe depletion, but that $\mathrm{FeO}^{*}$ starts to increase slowly with a decrease in $\mathrm{MgO}$ from $8.0 \mathrm{wt}$. \% of MgO. At the same time, the FSR $117^{\circ} \mathrm{E}-\mathrm{N}$ and NFSR basalts more closely match with the LLD simulated under anhydrous conditions (red LLD in Figure 7 with $0.07 \%$ modeling water content and gray area). The filtered data for the FSR $117^{\circ} \mathrm{E}-\mathrm{C}$ basalt shows a relatively strong Fe depletion, and the scattered data suggest a large variation in the magma water content (Figure 7: yellow area). Defining the degree of Fe depletion from the filtered data for the FSR $114.9-115.0^{\circ} \mathrm{E}$ basalts is more difficult, because the basalt $\mathrm{MgO}$ value here is relatively more concentrated (MgO: 5.44-7.56 wt. \%) and cannot reflect the trend of magma evolution well. Even so, the data appears to be scattered between the two LLDs simulated under anhydrous (red LLD in Figure 7 with $0.07 \%$ modeling water content) and hydrous conditions (blue LLD in Figure 7 with $1.0 \%$ modeling water content), which suggests a wider range of magma water content variation.
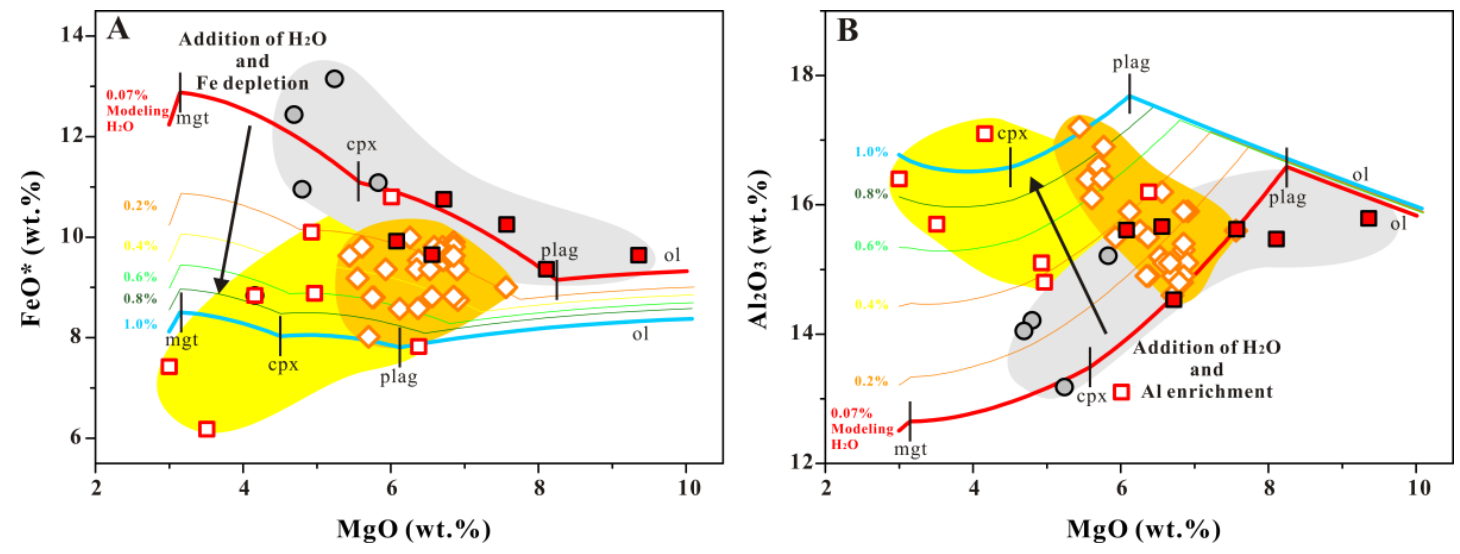

Figure 7. Plot of the filtered $\mathrm{MgO}$ vs. $\mathrm{FeO}^{*}(\mathbf{A})$ and $\mathrm{MgO}$ vs. $\mathrm{Al}_{2} \mathrm{O}_{3}$ (B) for SCS basalts with liquid lines of descent (LLDs). LLDs were calculated using the Petrolog3 software package [74], with multiphase fractionation of olivine $(\mathrm{ol})+$ plagioclase $(\mathrm{plag})+$ clinopyroxene $(\mathrm{cpx})+$ magnetite $(\mathrm{mgt})$ modeled at variable water contents; the mineral-melt equilibrium models of Weaver and Langmuir [75] were used for olivine and clinopyroxene, the model of Danyushevsky [32] was used for plagioclase, and the model of Ariskin and Barmina [76] was used for magnetite. The red LLD represents anhydrous conditions with $0.07 \%$ water $+1 \mathrm{kbar}$, and the blue LLD represents hydrous conditions with $1.0 \%$ water $+1 \mathrm{kbar}$. The thin lines in the middle represent the change in LLDs with variation in water content only, instead of the change with crystallization pressure $(\mathrm{P})$ and oxygen fugacity $\left(f \mathrm{O}_{2}\right)$. The $\mathrm{P}$ and $f \mathrm{O}_{2}$ also affect the shape of the LLD curves, but they do not cause significant Fe depletion and $\mathrm{Al}$ enrichment. As water content increases, Fe gradually depletes, and $\mathrm{Al}$ gradually enriches. The decrease in $\mathrm{Fe}_{8.0}$ is dominated by the effect $\mathrm{H}_{2} \mathrm{O}$ on low-pressure differentiation [39]. The symbols in this figure represent the same things as those in Figure 2. 


\subsection{Magma Water Content Variation along the FSR}

By studying the characteristics of mantle melting and magma fractional crystallization, we attempt to infer the magma water content variation trends along the FSR. First, the lava from the FSR $116.2^{\circ} \mathrm{E}$, FSR $117.7^{\circ} \mathrm{E}$, and NFSR basalts is considered normal lava under the SCS, because they have similar mantle source isotope compositions, degrees of Fe depletion, and melting characteristics, even though FSR $116.2^{\circ} \mathrm{E}$ has much lower melt fractions and initial melting depth. Thus, they have normal water content in the magma. Second, the lava from the FSR $117^{\circ} \mathrm{E}-\mathrm{C}$ and $117^{\circ} \mathrm{E}-\mathrm{N}$ basalts contain higher and lower magma water content than that of normal lava, respectively, due to the following reasons:

(1) Notice that even though the $117^{\circ} \mathrm{E}-\mathrm{N}$ basalt has slightly lower ${ }^{87} \mathrm{Sr} /{ }^{86} \mathrm{Sr},{ }^{206} \mathrm{~Pb} /{ }^{204} \mathrm{~Pb}$ and higher ${ }^{143} \mathrm{Nd} /{ }^{144} \mathrm{Nd}$ isotope composition than the surrounding basalt, as a result of the weaker influence of the Hainan mantle plume (Figure 8). However, there is no other mantle contamination displayed here. Hence, we suggest that the lavas in these two groups have similar mantle source isotope compositions to that of SCS normal lava. This is an important prerequisite for comparison of their magma water contents.

(2) The lava from FSR $117^{\circ}$ E-C shows high Fe depletion, which reflects additional water content in the magma there, while that of the FSR $117^{\circ} \mathrm{E}-\mathrm{N}$ does not (Figure 7 ).

(3) The FSR $117^{\circ} \mathrm{E}-\mathrm{C}$ basalt exhibits the lowest degree of melting and highest initial melting depth, which are consistent with the results for additional water in the mantle. In contrast, the FSR $117^{\circ} \mathrm{E}-\mathrm{N}$ basalt shows the highest melting degree and lowest initial melting depth.

(4) As mentioned in Section 5.1, the concentrations of different incompatible elements depend on the different degree of melting or on the mantle source. Therefore, based on the degree of melting revealed from the trace elements melting model (Figure 7, the $117^{\circ} \mathrm{E}-\mathrm{C}$ basalt $5-10 \%$; the $117^{\circ} \mathrm{E}-\mathrm{N}$ basalt $>25 \%$; and the SCS normal basalt 6-20\%), and specifically the basalt Ce concentration (for the $117^{\circ} \mathrm{E}-\mathrm{C}$ basalt 75-201 ppm; the $117^{\circ} \mathrm{E}-\mathrm{N}$ basalt 5.3-19.1 ppm; the SCS normal basalt 13.9-149 ppm), we used the batch melting equation and $\mathrm{D}_{\mathrm{Ce}}(0.01$; Johnson et al., [77]) to calculate the Ce concentration of the mantle source. The reason why we use the F value revealed from the trace elements melting model is not due to the $\mathrm{F}$ value being more accurate than the result calculated from $\mathrm{TiO}_{2(\mathrm{Fo} 90)}$. If the $\mathrm{Ce}$ concentration of the mantle source remains high under the calculation of overestimated $F$, then it would be more able to explain that the mantle source should be "wet". The results show that the average Ce in the mantle source is about $9.6 \pm 3.0$ ppm for the $117^{\circ} \mathrm{E}-\mathrm{C}$ basalt, $2.4 \pm 1.1 \mathrm{ppm}$ for the $117^{\circ} \mathrm{E}-\mathrm{N}$ basalt, and $7.8 \pm 1.5 \mathrm{ppm}$ for the SCS normal basalt group. Since Ce has mineral and bulk mantle/melt partition coefficients similar to those of water $[70,78]$, the highest $\mathrm{Ce}$ concentration in the $117^{\circ} \mathrm{E}-\mathrm{C}$ mantle source suggests that the mantle should be "wet".

It is difficult to assess whether the magma water content of the FSR $114.9-115.0^{\circ} \mathrm{E}$ lava is higher or lower than that of the SCS normal lava. Due to the significant differences in the mantle source isotope compositions, even though the calculated Ce concentration $(3.9 \pm 0.5 \mathrm{ppm})$ of the mantle source is similar with $117^{\circ} \mathrm{E}-\mathrm{N}$, we cannot conclude that its mantle source should be "dry". For example, because of the differences in the mantle source, the $\mathrm{H}_{2} \mathrm{O} / \mathrm{Ce}$ ratio of global mid-ocean ridge systems have a relatively wide variation range from 150 to 280 [22,79]. From the perspective of fractional crystallization, the lava from the $114.9-115.0^{\circ} \mathrm{E}$ basalt does not fit well with any of the LLDs with different conditions. However, the large variation ranges for $\mathrm{FeO}^{*}$ and $\mathrm{Al}_{2} \mathrm{O}_{3}$ exhibited by the lava can be well matched to the range covered by the multiple LLDs corresponding to the increasing magma water content (Figure 7). This indicates that lava from the 114.9-115.0 $\mathrm{E}$ basalts contain higher water content and also a greater variation than the normal lava underneath SCS. 


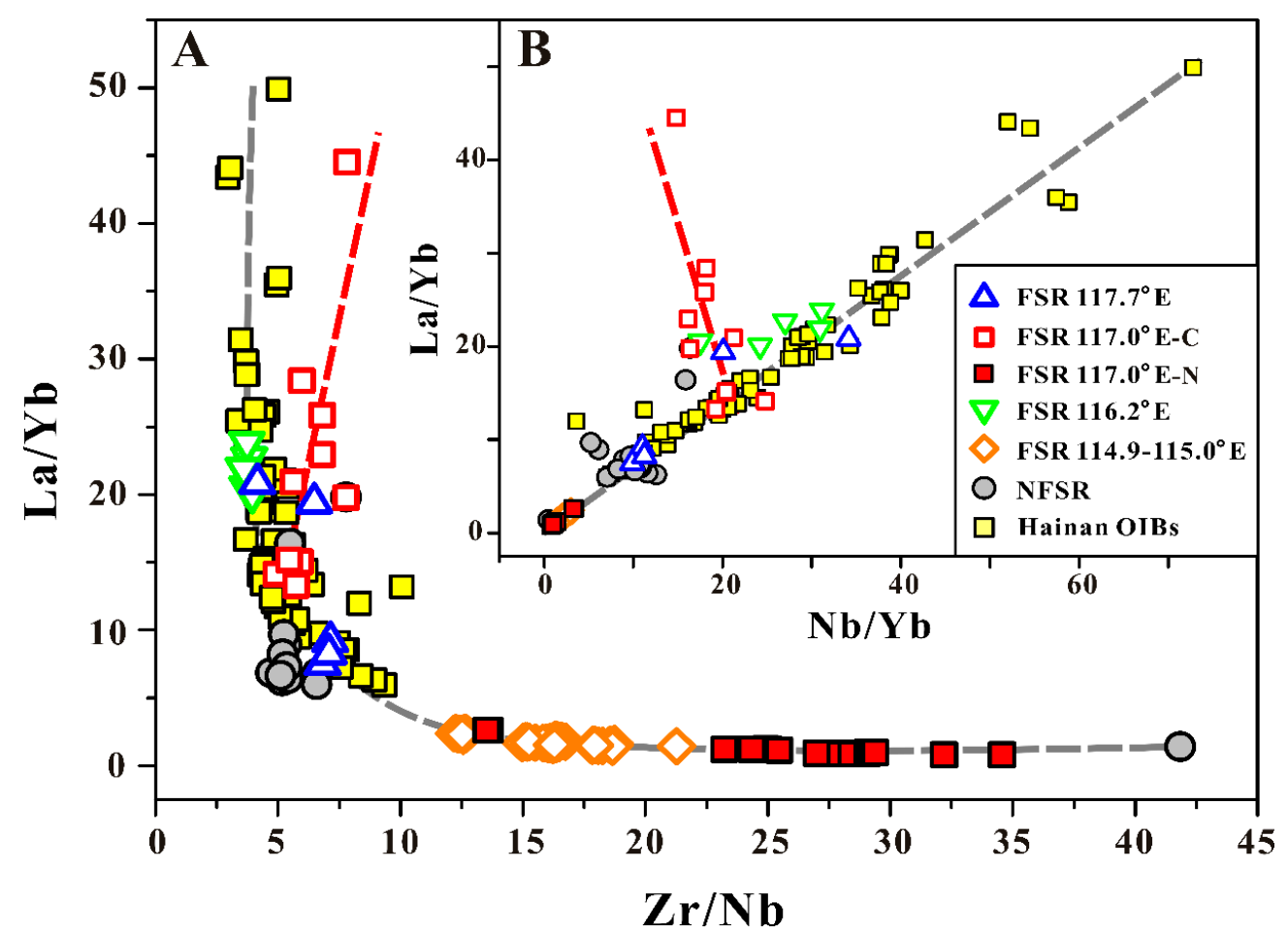

Figure 8. A: $\mathrm{La} / \mathrm{Yb}$ versus $\mathrm{Zr} / \mathrm{Nb}$ for the $\mathrm{SCS}$ basalt. B: $\mathrm{La} / \mathrm{Yb}$ versus $\mathrm{Nb} / \mathrm{Yb}$ for the $\mathrm{SCS}$ basalt. The Hainan OIB data from Zou and Fan [15], Li et al. [16], Wang et al. [52] and Han et al. [53].

\subsection{Constraining Mantle Heterogeneity}

\subsubsection{The Hainan Mantle Plume}

Previous research has shown that an Indian-type mantle source (Dupal anomaly) beneath the SCS with the evidence of isotope composition $[9,15-17,47,50,80,81]$ and Hainan mantle plume influence played a significant role $[9,15-18,50]$. The geochemical and isotopic features of SCS basalts also recorded that plume-ridge source mixing perhaps appears, since $23.8 \mathrm{Ma}$ [82]. Here, we used incompatible trace element ratios $(\mathrm{La}, \mathrm{Yb}, \mathrm{Zr}$, and $\mathrm{Nb})$ to determine whether the SCS mantle source was influenced by the Hainan plume or could have resulted from the mixing of Hainan plume material with the local depleted MORB mantle (DMM). These trace element ratios are not significantly affected by the magma differentiation because the lack of garnet participated in the process of magma differentiation, and the addition of olivine will not affect these ratios. All the basalt data from SCS, except for that of FSR $117^{\circ} \mathrm{E}-\mathrm{C}$, fit well with the Hainan OIBs in the same mixing curves (the gray dotted lines in Figure $8 \mathrm{~A}, \mathrm{~B})$. In Figure $8 \mathrm{~A},(\mathrm{Zr} / \mathrm{Nb}$ versus $\mathrm{La} / \mathrm{Yb})$, it can be clearly seen that both the SCS basalt and Hainan OIBs result from mixing the same two components along a curve, and this mixing hypothesis is also supported by the companion plot in Figure $8 \mathrm{~B}(\mathrm{Nb} / \mathrm{Yb}$ versus $\mathrm{La} / \mathrm{Yb})$. The Hainan OIBs have the most enriched composition and can be used as end members in the mixing model, which suggests that Hainan plume materials played a dominant role in deciding the geochemistry of most SCS basalts. Note that some SCS basalt samples have enrichment similar to those of Hainan OIBs, suggesting a strong influence of the Hainan plume. In contrast, the lowest $\mathrm{La} / \mathrm{Yb}$ and $\mathrm{Nb} / \mathrm{Yb}$ ratios and highest $\mathrm{Zr} / \mathrm{Nb}$ ratio in the FSR $117^{\circ} \mathrm{E}-\mathrm{N}$ and $114.9-115.0^{\circ} \mathrm{E}$ basalts indicate the weakest influence of the Hainan plume. This can explain the isotope composition well (slightly smaller ${ }^{87} \mathrm{Sr} /{ }^{86} \mathrm{Sr}$ and ${ }^{206} \mathrm{~Pb} /{ }^{204} \mathrm{~Pb}$ values, and higher ${ }^{143} \mathrm{Nd} /{ }^{144} \mathrm{Nd}$ values than the surrounding basalt), as well as the sub-alkaline characteristics and N-MORB (or E-MORB) such as REE and incompatible trace element patterns (Supplementary Section S1). A recent study of the measurement of the water content of early crystallized cpx phenocryst of Hainan basalts show that the primary melts of Hainan basalts can be estimated to range from 0.28 to $1.24 \mathrm{wt}$. \% with an average of $0.54 \pm 0.29 \mathrm{wt}$. \% [83], which are significantly higher values than 
the normal N-MORB. Thus, the weakest influence of Hainan plume on the $117^{\circ} \mathrm{E}-\mathrm{N}$ basalts can also explain well the lowest water concentration in its magma. Further, this suggests that there could be other contamination materials in the mantle beneath the $114.9-115.0^{\circ} \mathrm{E}$.

However, the FSR $117^{\circ} \mathrm{E}-\mathrm{C}$ basalt data show entirely different trend curves from those of the others, with a higher $\mathrm{La} / \mathrm{Yb}$ ratio and relatively stable $\mathrm{Zr} / \mathrm{Nb}$ and $\mathrm{Nb} / \mathrm{Yb}$ ratios. These features imply that another material with enriched $\mathrm{La}$ and depleted $\mathrm{Nb}$, instead of the Hainan plume, determined the chemical concentration and affected the water content in the mantle source there.

\subsubsection{Carbonated Silicate Melts}

Zhang et al. [9] identified that natural carbonated silicate melts exist in the shallow mantle underneath the SCS and penetrate through the hot asthenosphere, finally converting to alkali basaltic melts in the FSR $117^{\circ} \mathrm{E}-\mathrm{C}$ basalt. Thus, the carbonated melts have a significant influence on the water content of the lava from FSR $117^{\circ} \mathrm{E}-\mathrm{C}$. In order to determine whether carbonated silicate melts are enriched in the water, it is necessary to recognize their origins.

The mantle source of the carbonated melts is of deep origin, with the evidence of trace elements (higher $\mathrm{La} / \mathrm{Yb}$ and $\mathrm{La} / \mathrm{Sm}$ ). A depleted asthenospheric or lithospheric mantle has also been found to be involved with creating the existing isotopic composition. Based on the low $\mathrm{MgO}$ concentration, Zhang et al. [9] suggested that the carbonated melts are products of the melting of carbonated eclogite, and the relatively high ${ }^{206} \mathrm{~Pb} / 207 \mathrm{~Pb}$ ratio can be explained by the recycling of oceanic crust. Therefore, the subduction of the carbonated oceanic crust is considered an effective way to introduce carbonated eclogite to the mantle, and hydrous fluids are extracted during subduction. Hence, we suggest that the carbonated melts should be wet-even though the experimental data suggest that the water solubility of olivine is reduced by a factor of approximately two due to the presence of $\mathrm{CO}_{2}$ [84] - and propose that the content of water introduced by carbonated melts is still higher than that in the other groups of basalts in the SCS.

\subsubsection{Mantle Contamination beneath the $114.9-115.0^{\circ}$ E Basalts}

According to the characteristics of trace elements and the isotope composition, the FSR $114.9-115.0^{\circ} \mathrm{E}$ basalts indicate a weak Hainan mantle plume influence, with possibly other contamination in the mantle source. The large variations in the degrees of Fe depletion and $\mathrm{Al}$ enrichment during the magma fractional crystallization also suggest large variation in magma water content. Therefore, the contaminant must also be enriched in the water. In order to identify the factors responsible for the abnormal isotope composition and water-enriched lava, we performed principal component analysis (PCA) on the three kinds of $\mathrm{Pb}$ isotope compositions $\left({ }^{206} \mathrm{~Pb} /{ }^{204} \mathrm{~Pb},{ }^{207} \mathrm{~Pb} /{ }^{204} \mathrm{~Pb}\right.$, and ${ }^{208} \mathrm{~Pb} /{ }^{204} \mathrm{~Pb}$ ) of the SCS basalt. The details of the calculations are provided in Supplementary Section S4 and the calculated results of the attribution of three principal components are shown in the Supplementary Table S3.

The PCA (Figure 9) showed that of the $99.52 \%$ total variability of the SCS basalt Pb isotope composition, $96.07 \%$ is attributed to the first principal component (PC1), and the second (PC2) is responsible for $3.45 \%$. Hence, PCA performs well in converting three-dimensional (3D) $\mathrm{Pb}$ isotope data $\left({ }^{206} \mathrm{~Pb} /{ }^{204} \mathrm{~Pb},{ }^{207} \mathrm{~Pb} /{ }^{204} \mathrm{~Pb}\right.$, and ${ }^{208} \mathrm{~Pb} /{ }^{204} \mathrm{~Pb}$ ) into two-dimensional (2D) representational forms (PC1 and PC2). In order to distinguish between binary and ternary mixing, we chose DMM, enriched mantle type II (EMII), a focus zone (FOZO), and lower continental crust (LCC) as end members in the PCA. A large amount of Sr-Nd-Pb isotope composition data for the SCS basalt indicate that the SCS sub-basin mantle was generated through binary mixing between DMM and EMII [11,13,85]; thus, DMM and EMII were chosen as PCA end members. The FOZO has moderate $\mathrm{Sr}-\mathrm{Nd}-\mathrm{Pb}$ isotope signatures and elevated ${ }^{3} \mathrm{He} /{ }^{4} \mathrm{He}$ ratios [86], which points to having deep origins and more primitive source materials than MORB $[87,88]$. LCC has been chosen as the water-enriched end member based on the experimentally measured water concentration $[89,90]$. However, the water in the LCC does not 
exist in the fluid form [80], but rather is reserved within the NAMs' structure, such as orthopyroxene, clinopyroxene, feldspar, olivine, and garnet, and constitutes a significant reservoir [91].

The results of PCA that are presented in Figure 9 show that four different mantle end members fall exactly into four different quadrants, forming triangles with respect to each other. The LCC shows the highest PC1 and lowest PC2 values, whereas FOZO shows the lowest PC1 and highest PC2 values. The average of Hainan OIBs principal components are really close to that of the EMII; it also shows a slight contamination with the continental lithosphere. Obviously, all the SCS basalts cannot be considered the result of simple binary mixing between DMM and EMII. The FSR $117.7^{\circ}$ E, FSR $117^{\circ} \mathrm{E}-\mathrm{C}, \mathrm{NFSR}$, and some of the FSR $117^{\circ} \mathrm{E}-\mathrm{N}$ basalt data showed ternary mixing between DMM, EMII, and FOZO, reflecting the influence of the mantle plume and indicating deep origin. However, the $116.2^{\circ} \mathrm{E}$ basalt does not show any FOZO-like source, which corresponds to its lowest initial melting depth.

Further, the FSR 114.9-115.0 $0^{\circ}$ basalts show a significant difference with others along the PC1 axis; the FSR 114.9-115.0 E basalts plot in the area with PC1 >0, while the others plot in the area with PC1 $<0$. Thus, its data show another ternary mix of DMM, EMII, and LCC. Obviously, the influence of the Hainan mantle plume is weak, and the data more likely show binary mixing between DMM and LCC. Thus, we suggest that the LCC has the dominant role in controlling the basalt chemistry of FSR 114.9-115. $0^{\circ} \mathrm{E}$, which reveals mantle contamination with LCC materials. The possible explanation for contamination with LCC materials may be that they were recycled in the convective mantle during continental break-up [9].

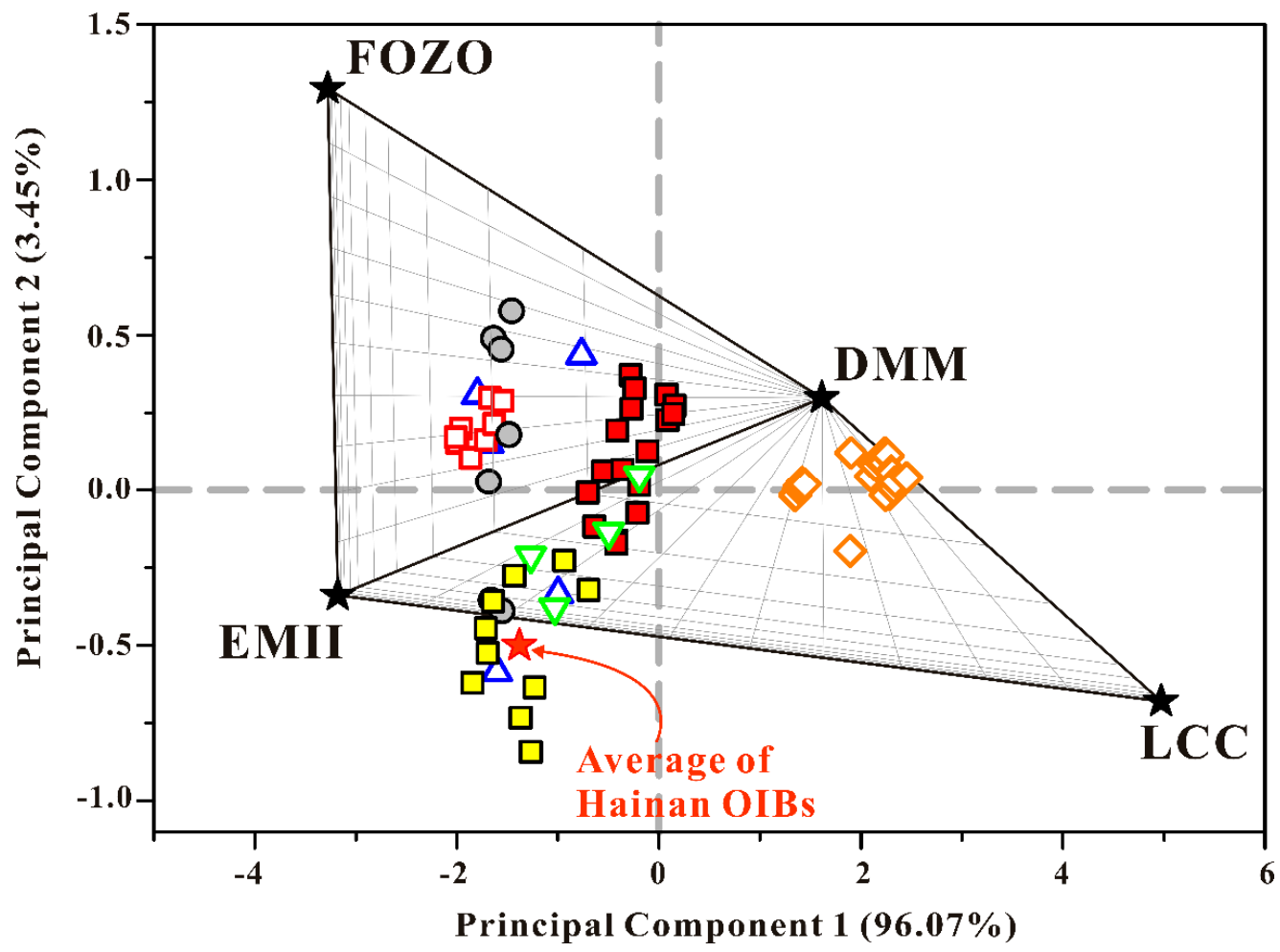

Figure 9. Principal component analysis of ${ }^{206} \mathrm{~Pb} /{ }^{204} \mathrm{~Pb},{ }^{207} \mathrm{~Pb} / 204 \mathrm{~Pb}$, and ${ }^{208} \mathrm{~Pb} /{ }^{204} \mathrm{~Pb}$ for the SCS basalts. The first principal component explains $96.07 \%$ of the total variability of the SCS basalt data, and the second explains $3.45 \%$. Hence, this two-dimensional (2D) representation of the three-dimensional (3D) dataset shows $99.52 \%$ of the total variability. Data for the Hainan OIBs are from Zou and Fan [15] and Li et al. [16]. Data for the lower continental crust (LCC) are from Escrig et al. [92]. Data for the mantle end members depleted MORB mantle (DMM), enriched mantle type II (EMII), and the focus zone (FOZO) are from Hart [61] and Armienti and Gasperini [93]. The details of the calculation are shown in Supplementary Section S4. The symbols in this figure represent the same things as those in Figure 8. 


\section{Conclusions}

Magmatic water content variations along the FSR were identified by comparing the degree of Fe depletion, partial melting characteristics, and mantle source composition of different groups basalts at different longitudes. The lava from FSR $116.2^{\circ} \mathrm{E}$, FSR $117.7^{\circ} \mathrm{E}$, and NFSR can be considered normal lava for the SCS with normal water concentration. The lava from FSR $117^{\circ} \mathrm{E}-\mathrm{C}$ contains much higher magma water content and shows evidence of strong Fe depletion, the lowest degree of melting, and relatively enriched Ce concentration in the mantle source. The origin of the FSR $117^{\circ} \mathrm{E}-\mathrm{C}$ basalt group at a "wet" mantle source is related to its content of carbonated silicate melts. However, due to the weak influence of the Hainan mantle plume, the lava from FSR $117^{\circ} \mathrm{E}-\mathrm{N}$ exhibited much lower magma water content. The lava from FSR 114.9-115.0 $0^{\circ} \mathrm{E}$ also presented high water content and a unique mantle source isotopic composition. The PCA of $\mathrm{Pb}$ isotopes suggests the origin of the water-rich magma in FSR $114.9-115.0^{\circ} \mathrm{E}$ is related to contamination with LCC materials.

In conclusion, we suggest that there is a mantle source compositional transition area between the southwestern and eastern sub-basins, which have different mantle evolution histories beneath the FSR. The mantle source beneath the southwestern sub-basin was contaminated by LCC materials that may have been recycled by the convective mantle during continental break-up. The mantle source beneath the eastern sub-basin was strongly influenced by the Hainan mantle plume and carbonated silicate melts.

Supplementary Materials: The following are available online at http://www.mdpi.com/2075-163X/9/7/410/s1, Table S1: The calculated parameters of SCS basalt; Table S2: The comparison of two methods for calculating F; Table S3: The attribution of three principal components; Figure S1: The TAS diagam of SCS basalt data; Figure S2: The chondrite-normalized REE patterns of SCS basalt data; Figure S3: The primitive mantle-normalized incompatible trace element patterns of SCS basalt data.

Author Contributions: W.W. and F.C. conceived and designed the concept of this study; W.W. and X.W. wrote this paper; Z.L., L.C., X.L., Y.Y. and J.Z. have substantially revised the original manuscript.

Funding: This research project was jointly funded by National Research Plan of China (Grant number 2016YFC0301803), the "13th Five-Year Plan" for Resources and Environment Projects of the China Ocean Mineral R\&D Association (COMRA) (DY135-N1-1; DY135-G2-1; DY135-G2-1-02; DY135-C1-1-07), National Natural Science Foundation of China (Grant No. 41706041, 41706044, 41506073).

Acknowledgments: We thank the two reviewers for their constructive comments, and editors for the editorial handling.

Conflicts of Interest: The authors declare no conflict of interest.

\section{References}

1. Taylor, B.; Hayes, D.E. The tectonic evolution of the South China Basin. In The Tectonic and Geologic Evolution of Southeast Asian Seas and Islands, Part 1; Hayes, D.E., Ed.; American Geophysical Union: Washington, DC, USA, 1980; pp. 89-104.

2. Taylor, B.; Hayes, D.E. Origin and history of the South China Sea basin. In The Tectonic and Geologic Evolution of Southeast Asian Seas and Islands, Part 2; Hayes, D.E., Ed.; American Geophysical Union: Washington, DC, USA, 1983; pp. 23-56.

3. Morley, C.K. A tectonic model for the Tertiary evolution of strike-slip faults and rift basins in SE Asia. Tectonophysics 2002, 347, 189-215. [CrossRef]

4. Sun, Z.; Zhou, D.; Zhong, Z.H.; Xia, B.; Qiu, X.L.; Zeng, Z.X.; Jiang, J.Q. Research on the dynamics of the South China Sea opening: Evidence from analogue modeling. Sci. China (Ser. D) 2006, 49, 1053-1069. [CrossRef]

5. Sun, Z.; Zhong, Z.H.; Keep, M.; Zhou, D.; Cai, D.S.; Li, X.S.; Wu, S.M.; Jiang, J.Q. 3D analogue modeling of the South China Sea: A discussion on breakup pattern. J. Asian Earth Sci. 2009, 34, 544-556. [CrossRef]

6. Xia, B.; Zhang, Y.; Cui, X.J.; Liu, B.M.; Xie, J.H.; Zhang, S.L.; Lin, G. Understanding of the geological and geodynamic controls on the formation of the South China Sea: A numerical modelling approach. J. Geodyn. 2006, 42, 63-84. [CrossRef]

7. Xu, Y.G.; Wei, J.X.; Qiu, H.N.; Zhang, H.H.; Huang, X.L. Opening and evolution of the South China Sea constrained by studies on volcanic rocks: Preliminary results and a research design. Chin. Sci. Bull. 2012, 57, 3150-3164. [CrossRef] 
8. Sun, W.D. Initiation and evolution of the South China Sea: An overview. Acta Geochim. 2016, 35, $215-225$. [CrossRef]

9. Zhang, G.L.; Chen, L.H.; Jackson, M.G.; Hofmann, A.W. Evolution of carbonated melt to alkali basalt in the South China Sea. Nat. Geosci. 2017, 10, 229-235. [CrossRef]

10. Tu, K.; Flower, M.; Carlson, R.W.; Xie, G.; Chen, C.Y.; Zhang, M. Magmatism in the South China Basin: 1. Isotopic and trace-element evidence for an endogenous Dupal mantle component. Chem. Geol. 1992, 97, 47-63. [CrossRef]

11. Yan, Q.S.; Shi, X.F.; Wang, K.S.; Pu, W.R.; Xiao, L. The study of major, trace and Sr-Nd-Pb isotope composition of Cenozoic alkaline basalt in the South China Sea. Sci. China 2008, 38, 56-71.

12. Li, C.F.; Lin, J.; Dadd, K.A. Site U1431-1343. Proc. Int. Ocean Discov. Program. 2015, 349, 1-22.

13. Zhang, G.L.; Luo, Q.; Zhao, J.; Jackson, M.G.; Guo, L.S.; Zhong, L.F. Geochemical nature of sub-ridge mantle and opening dynamics of the South China Sea. Earth Planet. Sci. Lett. 2018, 489, 145-155. [CrossRef]

14. Dupré, B.; Allègre, C.J. Pb-Sr isotope variation in Indian Ocean basalts and mixing phenomena. Nature 1983, 303, 142-146. [CrossRef]

15. Zou, H.; Fan, Q. U-Th isotopes in Hainan basalts: Implications for sub-asthenospheric origin of EM2 mantle endmember and the dynamics of melting beneath Hainan Island. Lithos 2010, 116, 145-152. [CrossRef]

16. Li, N.; Yan, Q.; Chen, Z.; Shi, X. Geochemistry and petrogenesis of Quaternary volcanism from the islets in the eastern Beibu Gulf: Evidence for Hainan plume. Acta Oceanol. Sin. 2013, 32, 40-49. [CrossRef]

17. Wang, Z.L.; Xu, D.R.; Wu, C.J.; Fu, W.W.; Wang, L.; Wu, J. Discovery of the Late Paleozoic ocean island basalts (OIB) in Hainan Island and their geodynamic implications. Acta Oceanol. Sin. 2013, 29, 875-886.

18. Yan, Q.S.; Shi, X.F. Hainan mantle plume and the formation and evolution of the South China Sea. Geol. J. China Univ. 2007, 13, 311-322.

19. Hirth, G.; Kohlstedt, D.L. Water in the oceanic upper mantle: Implications for rheology, melt extraction and the evolution of the lithosphere. J. Earth Planet. Sci. Lett. 1996, 144, 93-108. [CrossRef]

20. Sobolev, A.V.; Chaussidon, $\mathrm{M} . \mathrm{H}_{2} \mathrm{O}$ concentrations in primary melts from supra-subduction zones and mid-ocean ridges: Implications for $\mathrm{H}_{2} \mathrm{O}$ storage and recycling in the mantle. J. Earth Planet. Sci. Lett. 1996, 137, 45-55. [CrossRef]

21. Thompson, A.B. Water in the Earth's upper mantle. Nature 1992, 358, 295-302. [CrossRef]

22. Michael, P.J. Regionally distinctive sources of depleted MORB: Evidence from trace elements and $\mathrm{H}_{2} \mathrm{O}$. Earth Planet. Sci. Lett. 1995, 131, 301-320. [CrossRef]

23. Dixon, J.E. Volatiles in Basaltic Glasses from Loihi Seamount, Hawaii: Evidence for a Relatively Dry Plume Component. J. Petrol. 2001, 42, 627-654. [CrossRef]

24. Plank, T.; Kelley, K.A.; Zimmer, M.M.; Hauri, E.H.; Wallace, P.J. Why do mafic arc magmas contain-4 wt. \% water on average? Earth Planet. Sci. Lett. 2013, 364, 168-179. [CrossRef]

25. O'Leary, J.A.; Gaetani, G.A.; Hauri, E.H. The effect of tetrahedral $\mathrm{Al}^{3+}$ on the partitioning of water between clinopyroxene and silicate melt. Earth Planet. Sci. Lett. 2010, 297, 111-120. [CrossRef]

26. Wade, J.A.; Plank, T.; Hauri, E.H.; Kelley, K.A.; Roggensack, K.; Zimmer, M. Prediction of magmatic water contents via measurement of $\mathrm{H}_{2} \mathrm{O}$ in clinopyroxene phenocrysts. Geology 2008, 36, 799-802. [CrossRef]

27. Xia, Q.K.; Liu, J.; Liu, S.C.; Kovacs, I.; Feng, M.; Dang, L. High water content in Mesozoic primitive basalts of the North China Craton and implications on the destruction of cratonic mantle lithosphere. Earth Planet. Sci. Lett. 2013, 361, 85-97. [CrossRef]

28. Yan, J.Y.; Li, X.P.; Yan, Q.S. Geochemical characteristics and geological implications of clinopyroxenes in Cenozoic basalts from the South China Sea. Geol. Rev. 2014, 60, 824-838.

29. Yan, Q.S.; Shi, X.F.; Wang, Q.S.; Bu, R.W. Mineral chemistry and its genetic significance of olivine in Cenozoic basalts from the South China Sea. Acta Petrol. Sin. 2007, 21, 2981-2989.

30. Kinzler, R.J. Melting of mantle peridotite at pressures approaching the spinel to garnet transition: Application to mid-ocean ridge basalt petrogenesis. J. Geophys. Res. 1997, 102, 853-874. [CrossRef]

31. Bédard, J.H. Parameterization of the $\mathrm{Fe}=\mathrm{Mg}$ exchange coefficient $(\mathrm{Kd})$ between clinopyroxene and silicate melts. Chem. Geol. 2010, 274, 169-176. [CrossRef]

32. Danyushevsky, L.V. The effect of small amounts of $\mathrm{H}_{2} \mathrm{O}$ on crystallisation of mid-ocean ridge and backarc basin magmas. J. Volcan. Geoth. Res. 2001, 110, 265-280. [CrossRef]

33. Green, T.H.; Ringwood, A.E. Crystallization of basalt and andesite under high pressure hydrous conditions. Earth Planet. Sci. Lett. 1967, 3, 481-489. [CrossRef] 
34. Sisson, T.W.; Grove, T.L. Experimental investigations of the role of $\mathrm{H}_{2} \mathrm{O}$ in calc-alkaline differentiation and subduction zone magmatism. Contrib. Mineral. Petrol. 1993, 113, 143-166. [CrossRef]

35. Langmuir, C.H.; Hanson, G.N.; O'Hara, M.J. An Evaluation of Major Element Heterogeneity in the Mantle Sources of Basalts. Philos. Trans. R. Soc. Lond. 1980, 297, 383-407. [CrossRef]

36. Grove, T.L.; Bryan, W.B. Fractionation of pyroxene-phyric MORB at low pressure: An experimental study. Contrib. Mineral. Petrol. 1983, 84, 293-309. [CrossRef]

37. Langmuir, C.H.; Klein, E.M.; Plank, T. Petrological systematics of mid-Ocean ridge basalts: Constraints on melt generation beneath ocean ridges. Mantle Flow Melt Gener. Mid-Ocean. Ridges 1992, 71, 183-280.

38. Zimmer, M.M.; Plank, T.; Hauri, E.H.; Yogodzinski, G.M.; Stelling, P.; Larsen, J.; Singer, B.; Jicha, B.; Mandeville, C.; Nye, C.J. The Role of Water in Generating the Calc-alkaline Trend: New Volatile Data for Aleutian Magmas and a New Tholeiitic Index. J. Petrol. 2010, 51, 2411-2444. [CrossRef]

39. Asimow, P.D.; Langmuir, C.H. The importance of water to oceanic mantle melting regimes. Nature 2003, 421, 815-820. [CrossRef]

40. Cande, S.C.; Kent, D.V. Revised calibration of the geomagnetic polarity timescale for the Late Cretaceous and Cenozoic. J. Geophys. Res. 1995, 100, 6093-6095. [CrossRef]

41. Hsu, S.K.; Yeh, Y.C.; Doo, W.B.; Tsai, C.H. New Bathymetry and Magnetic Lineations Identifications in the Northernmost South China Sea and their Tectonic Implications. Mar. Geophys. Res. 2004, 25, $29-44$. [CrossRef]

42. Briais, A. Updated Interpretation of Magnetic Anomalies and Seafloor Spreading Stages in the South China Sea: Implications for the Tertiary Tectonics of Southeast Asia. J. Geophys. Res. Solid Earth 2011, 98, 6299-6328. [CrossRef]

43. Li, C.; Xu, X.; Lin, J.; Song, T. Ages and magnetic structures of the South China Sea constrained by deep tow magnetic surveys and IODP Expedition 349. Geochem. Geophys. Geosyst. 2014, 15, 4958-4983. [CrossRef]

44. Braitenberg, C.; Wienecke, S.; Wang, Y. Basement structures from satellite-derived gravity field: South China Sea ridge. J. Geophys. Res. 2006, 111, B05407. [CrossRef]

45. Lebedev, S.; Nolet, G. Upper mantle beneath Southeast Asia from S velocity tomography. J. Geophys. Res. Solid Earth 2003, 108, 1-21. [CrossRef]

46. Nolet, G.; Allen, R.; Zhao, D. Mantle plume tomography. Chem. Geol. 2007, 241, 248-263. [CrossRef]

47. Hoàng, N.; Flower, M.F.J.; Carlson, R.W. Major, trace element, and isotopic compositions of Vietnamese basalts: Interaction of hydrous EM1-rich asthenosphere with thinned Eurasian lithosphere. Geochim. Cosmochim. Acta 1996, 60, 4329-4351. [CrossRef]

48. Zhou, P.; Mukasa, S.B. Nd-Sr-Pb isotopic, and major and trace-element geochemistry of Cenozoic lavas from the Khorat Plateau, Thailand: Sources and petrogenesis. Chem. Geol. 1997, 137, 175-193. [CrossRef]

49. Li, Z.G.; Chu, F.Y.; Dong, Y.H.; Liu, J.-Q.; Chen, L. Geochemical constraints on the contribution of Louisville seamount materials to magmagenesis in the Lau back-arc basin, SW Pacific. Int. Geol. Rev. 2015, 57, 978-997. [CrossRef]

50. Yan, Q.S.; Castillo, P.; Shi, X.; Wang, L.; Liao, L.; Ren, J. Geochemistry and petrogenesis of volcanic rocks from Daimao Seamount (South China Sea) and their tectonic implications. Lithos 2015, 218-219, 117-126. [CrossRef]

51. Yang, S.; Fang, N. Geochemical variation of volcanic rocks from the South China Sea and neighboring land: Implication for magmatic process and mantle structure. Acta Oceanol. Sin. 2015, 34, 112-124. [CrossRef]

52. Wang, X.C.; Li, Z.X.; Li, X.H.; Li, J.; Liu, Y.; Long, W.G.; Zhou, J.B.; Wang, F. Temperature, Pressure, and Composition of the Mantle Source Region of Late Cenozoic Basalts in Hainan Island, SE Asia: A Consequence of a Young Thermal Mantle Plume close to Subduction Zones? J. Petrol. 2012, 53, 177-233. [CrossRef]

53. Han, J.W.; Xiong, X.L.; Zhu, Z.Y. Geochemistry of late-Cenozoic basalts from Leiqiong area: The origin of EM2 and the contribution from sub-continental lithosphere mantle. Acta Petrol. Sin. 2009, 25, 3208-3220.

54. Hora, J.M.; Singer, B.S.; Worner, G.; Beard, B.L.; Jicha, B.R.; Johnson, C.M. Shallow and deep crustal control on differentiation of calc-alkaline and tholeiitic magma. Earth Planet. Sci. Lett. 2009, 285, 75-86. [CrossRef]

55. Ashchepkov, I.V.; Travin, S.V.; Saprykin, A.I.; Andre, L.; Gerasimov, P.A.; Khmel'nikova, O.S. Age of xenolith-bearing basalts and mantle evolution in the Baikal rift zone. Russ. Geol. Geophys. 2003, 44, 1160-1188. 
56. Herzberg, C.; Asimow, P.D. PRIMELT3 MEGA.XLSM software for primary magma calculation: Peridotite primary magma $\mathrm{MgO}$ contents from the liquidus to the solidus. Geochem. Geophys. Geosyst. 2015, 16, 563-578. [CrossRef]

57. Mryashiro, A. Volcanic rock series in island arcs and active continental margins. Am. J. Sci. 1974, 274, 321-355. [CrossRef]

58. Arculus, R.J. Use and abuse of the terms calcalkaline and calcalkalic. J. Petrol. 2003, 44, 929-935. [CrossRef]

59. Gale, A.; Dalton, C.A.; Langmuir, C.H.; Su, Y.; Schilling, J.-G. The mean composition of ocean ridge basalts. Geochem. Geophys. Geosyst. 2013, 14, 489-518. [CrossRef]

60. Lehnert, K.; Su, Y.; Langmuir, C.H.; Sarbas, B.; Nohl, U. A global geochemical database structure for rocks. Geochem. Geophys. Geosyst. 2000,1,1-14. [CrossRef]

61. Hart, S.R. A large-scale isotope anomaly in the Southern Hemisphere mantle. Nature 1984, 309, $753-757$. [CrossRef]

62. Klein, E.M.; Langmuir, C.H. Global correlations of ocean ridge basalt chemistry with axial depth and crustal thickness. J. Geophys. Res. Atmos. 1987, 92, 8089-8115. [CrossRef]

63. Pearce, J.A.; Parkinson, I.J. Trace element models for mantle melting: Application to volcanic arc petrogenesis. Geol. Soc. Lond. Spec. Public. 1993, 76, 373-403. [CrossRef]

64. Kelley, K.A.; Plank, T.; Grove, T.L.; Stolper, E.M.; Newman, S.; Hauri, E. Mantle melting as a function of water content beneath back-arc basins. J. Geophys. Res. 2006, 111, 1-27. [CrossRef]

65. Workman, R.K.; Hart, S.R. Major and trace element composition of the depleted MORB mantle (DMM). Earth Planet. Sci. Lett. 2005, 231, 53-72. [CrossRef]

66. Stolper, E.; Newman, S. The role of water in the petrogenesis of Mariana trough magmas. Earth Planet. Sci. Lett. 1994, 121, 293-325. [CrossRef]

67. Shibata, K. Geochronology of Pre-Silurian Basement Rocks in the Japanese Islands, with Special Reference to Age Determinations on Orthoquartzite Clasts; Basement of Japanese Islands, Memorial volume of Prof. Kano H.; Akita University: Akita, Japan, 1979; pp. 625-639.

68. Blundy, J.D.; Robinson, J.A.C.; Wood, B.J. Heavy REE are compatible in clinopyroxene on the spinel lherzolite solidus. Earth Planet. Sci. Lett. 1998, 160, 493-504. [CrossRef]

69. Xu, Y.G.; Ma, J.L.; Frey, F.A.; Feigenson, M.D.; Liu, J.F. Role of lithosphere-asthenosphere interaction in the genesis of Quaternary alkali and tholeiitic basalts from Datong, western North China Craton. Chem. Geol. 2005, 224, 247-271. [CrossRef]

70. Aubaud, C.; Hauri, E.H.; Hirschmann, M.M. Hydrogen partition coefficients between nominally anhydrous minerals and basaltic melts. Geophys. Res. Lett. 2004, 31, 235-241. [CrossRef]

71. Hirschmann, M.M.; Tenner, T.; Aubaud, C.; Withers, A.C.; Pepi, J. Dehydration melting of nominally anhydrous mantle: The primacy of partitioning. Phys. Earth Planet. Int. 2009, 176, 54-68. [CrossRef]

72. Lee, J.; Stern, R.J. Glass inclusions in Mariana Arc phenocrysts: A new perspective on magmatic evolution in a typical intra-oceanic arc. J. Geol. 1998, 106, 19-34. [CrossRef]

73. Meen, J.K.; Stern, R.J.; Bloomer, S.H. Evidence for magma mixing in the Mariana arc system. Isl. Arc 1998, 7, 443-459. [CrossRef]

74. Danyushevsky, L.V.; Plechov, P. Petrolog3: Integrated software for modeling crystallization processes. Geochem. Geophys. Geosyst. 2011, 12, 1-32. [CrossRef]

75. Weaver, J.S.; Langmuir, C.H. Calculation of phase equilibrium in mineral-melt systems. Comput. Geosci. 1990, 16, 1-19. [CrossRef]

76. Ariskin, A.A.; Barmina, G.S. An empirical model for the calculation of spinel-melt equilibria in mafic igneous systems at atmospheric pressure: 2. Fe-Ti oxides. Contrib. Mineral. Petrol. 1999, 134, 251-263. [CrossRef]

77. Johnson, K.T.M.; Dick, H.J.B.; Shimizu, N. Melting in the oceanic upper mantle: An ion microprobe study of diopsides in abyssal peridotites. J. Geophys. Res. 1990, 95, 2661-2678. [CrossRef]

78. Hauri, E.H.; Gaetani, G.A.; Green, T.H. Partitioning of water during melting of the Earth's upper mantle at $\mathrm{H}_{2} \mathrm{O}$-undersaturated conditions. Earth Planet. Sci. Lett. 2006, 248, 715-734. [CrossRef]

79. Dixon, J.E.; Leist, L.; Langmuir, C.; Schilling, J.G. Recycled dehydrated lithosphere observed in plume-influenced mid-ocean ridge basalt. Nature 2002, 420, 385-389. [CrossRef]

80. Chung, S.; Hai, C.; Jahn, B.; O'Reilly, S.Y.; Bingquan, Z. Major and trace element, and Sr-Nd isotope constraints on the origin of Paleogene volcanism in South China prior to the South China Sea opening. Lithos 1997, 40, $203-220$. [CrossRef] 
81. Hoàng, N.; Flower, M.F.J.; Xuân, P.T.; Quý, H.V.; Sơm, T.T. Collision-induced basalt eruptions at Pleiku and Buôn Mê Thuột, south-central Viet Nam. J. Geodyn. 2013, 69, 65-83. [CrossRef]

82. Yu, M.; Yan, Y.; Huang, C.Y.; Zhang, X.; Tian, Z.; Chen, W.; Santosh, M. Opening of the South China Sea and upwelling of the Hainan plume. Geophys. Res. Lett. 2018, 45, 2600-2609. [CrossRef]

83. Gu, X.Y.; Wang, P.Y.; Kuritani, T.; Hanski, E.; Xia, Q.; Wang, Q. Low water content in the mantle source of the Hainan plume as a factor inhibiting the formation of a large igneous province. Earth Planet. Sci. Lett. 2019, 515, 221-230. [CrossRef]

84. Yang, X.; Liu, D.; Xia, Q. $\mathrm{CO}_{2}$-induced small water solubility in olivine and implications for properties of the shallow mantle. Earth Planet. Sci. Lett. 2014, 403, 37-47. [CrossRef]

85. Zou, H.; Zindler, A.; Xu, X.; Qi, Q. Major, trace element, and Nd, Sr and Pb isotope studies of Cenozoic basalts in SE China: Mantle sources, regional variations, and tectonic significance. Chem. Geol. 2000, 171, 33-47. [CrossRef]

86. Hauri, E.H.; Whitehead, J.A.; Hart, S.R. Fluid dynamic and geochemical aspects of entrainment in mantle plumes. J. Geophys. Res. 1994, 99, 24275-24300. [CrossRef]

87. Hanan, B.B.; Graham, D.W. Lead and Helium Isotope Evidence from Oceanic Basalts for a Common Deep Source of Mantle Plumes. Science 1996, 272, 991-995. [CrossRef] [PubMed]

88. Allègre, C.J.; Hofmann, A.; O'Nions, K. The argon constraints on mantle structure. Geophys. Res. Lett. 1996, 23, 3555-3557. [CrossRef]

89. Yang, X.Z.; Deloule, E.; Xia, Q.K.; Fan, Q.; Feng, M. Water contrast between Precambrian and Phanerozoic continental lower crust in eastern China. J. Geophys. Res. 2008, 113, 1-12. [CrossRef]

90. Yang, G.C.; Yang, X.Z.; Hao, Y.T.; Xia, Q.K. Water content difference between continental lower crust and lithospheric mantle: Granulite and periditite xenoliths hosted in basalts from Junan, Shandong Province. Acta Petrol. Mineral. 2012, 31, 691-700.

91. Bell, D.R.; Rossman, G.R. Water in Earth's Mantle: The Role of Nominally Anhydrous Minerals. Science 1992, 255, 1391-1397. [CrossRef] [PubMed]

92. Escrig, S.; Capmas, F.; Dupré, B.; Allègre, C.J. Osmium isotopic constraints on the nature of the DUPAL anomaly from Indian mid-ocean-ridge basalts. Nature 2004, 431, 59-63. [CrossRef] [PubMed]

93. Armienti, P.; Gasperini, D. Do we really need mantle components to define mantle composition? J. Petrol. 2007, 48, 693-709. [CrossRef]

(C) 2019 by the authors. Licensee MDPI, Basel, Switzerland. This article is an open access article distributed under the terms and conditions of the Creative Commons Attribution (CC BY) license (http://creativecommons.org/licenses/by/4.0/). 